\title{
Distinctive gene and protein characteristics of extremely piezophilic Colwellia
}

\author{
Logan M. Peoples ${ }^{1,2}$, Than S. Kyaw', Juan A. Ugalde ${ }^{3}$, Kelli K. Mullane ${ }^{1}$, Roger A. Chastain ${ }^{1}$, A. Aristides Yayanos ${ }^{1}$, \\ Masataka Kusube ${ }^{4}$, Barbara A. Methé ${ }^{5}$ and Douglas H. Bartlett ${ }^{1 *}$
}

\begin{abstract}
Background: The deep ocean is characterized by low temperatures, high hydrostatic pressures, and low concentrations of organic matter. While these conditions likely select for distinct genomic characteristics within prokaryotes, the attributes facilitating adaptation to the deep ocean are relatively unexplored. In this study, we compared the genomes of seven strains within the genus Colwellia, including some of the most piezophilic microbes known, to identify genomic features that enable life in the deep sea.
\end{abstract}

Results: Significant differences were found to exist between piezophilic and non-piezophilic strains of Colwellia. Piezophilic Colwellia have a more basic and hydrophobic proteome. The piezophilic abyssal and hadal isolates have more genes involved in replication/recombination/repair, cell wall/membrane biogenesis, and cell motility. The characteristics of respiration, pilus generation, and membrane fluidity adjustment vary between the strains, with operons for a nuo dehydrogenase and a tad pilus only present in the piezophiles. In contrast, the piezosensitive members are unique in having the capacity for dissimilatory nitrite and TMAO reduction. A number of genes exist only within deep-sea adapted species, such as those encoding $d$-alanine-d-alanine ligase for peptidoglycan formation, alanine dehydrogenase for $\mathrm{NADH}_{\mathrm{NAD}}{ }^{+}$homeostasis, and a SAM methyltransferase for tRNA modification. Many of these piezophile-specific genes are in variable regions of the genome near genomic islands, transposases, and toxin-antitoxin systems.

Conclusions: We identified a number of adaptations that may facilitate deep-sea radiation in members of the genus Colwellia, as well as in other piezophilic bacteria. An enrichment in more basic and hydrophobic amino acids could help piezophiles stabilize and limit water intrusion into proteins as a result of high pressure. Variations in genes associated with the membrane, including those involved in unsaturated fatty acid production and respiration, indicate that membrane-based adaptations are critical for coping with high pressure. The presence of many piezophile-specific genes near genomic islands highlights that adaptation to the deep ocean may be facilitated by horizontal gene transfer through transposases or other mobile elements. Some of these genes are amenable to further study in genetically tractable piezophilic and piezotolerant deep-sea microorganisms.

Keywords: Piezophile, Colwellia, Deep sea, Hadal, Trench, Hydrostatic pressure, Genomic island

\section{Background}

The deep biosphere makes up one of the largest biomes on earth. An inherent environmental parameter present

\footnotetext{
* Correspondence: dbartlett@ucsd.edu

${ }^{1}$ Marine Biology Research Division, Scripps Institution of Oceanography, University of California San Diego, La Jolla, CA 92093-0202, USA

Full list of author information is available at the end of the article
}

throughout deep oceanic and subsurface habitats is high hydrostatic pressure. Elevated hydrostatic pressure influences many aspects of biochemistry and requires adaptations throughout the cell (e.g. [128]). One well-studied adaptation is the incorporation of unsaturated fatty acids into the membrane to combat physical changes such as decreased fluidity (e.g. $[3,29,30])$. Additional 
membrane-associated adaptations are linked to porinmediated nutrient transport $[11,12]$, respiration (e.g. $[141,144,145])$, and flagellar function [38]. Within the cell, changes in DNA replication, DNA structure, protein synthesis, and compatible solutes are also important [36, 67, 81, 148]. Pressure-induced changes in transcription implicate additional functions (e.g. [19, 92]). Despite the fact that pressure exerts a profound influence on the nature of life at depth, it is largely ignored in studies of deep-ocean biomes, and in marked contrast to microbial adaptation to temperature or salinity, a robust description of biochemical adaptation to high pressure is lacking.

Only a modest number of psychrophilic (cold-loving) and piezophilic (high-pressure loving) species have been isolated to date, in large part due to the constraints imposed by culturing under under in situ, high hydrostatic pressure conditions. However, metagenomic sequencing of deep-ocean communities, and additional analyses of individual microbial genomes, have provided insights. Metagenomic investigations have included locations within the North Pacific subtropical gyre, the Mediterranean and the Puerto Rico Trench [31, 39, 61, 86, 124]. Genomic studies include those on Pseudoalteromonas [116], Alteromonas [55], Shewanella [6, 142], Photobacterium [18, 70, 141], SAR11 [135], and members of the Thaumarchaeota [79, 130]. One picture that has emerged from the examinations at this level is that deep-sea microbes are enriched in mobile elements, such as phage and transposases [31, $39,55,68,69,72,116,124]$. This has been attributed to the relaxation of purifying selection as an adaptive mechanism [61], either to deep-ocean conditions or to the conditions found on particles [45]. Additional properties include an enrichment in heavy metal resistance genes $[39,43,55,116,124]$, the ability to use persistent dissolved organic material under oligotrophic conditions (e.g. [7, 55, 64, 86]), and widespread ability for chemoautotrophy [35, 94, 102, 129, 130]. The small number of genome sequences of experimentallyconfirmed deep-ocean piezophiles include hyperthermophilic archaea (Pyrococcus and Thermoccus [25, 58, 139];), a thermophilic bacterium (Marinitoga [78];), a mesophilic bacterium (Desulfovibrio [113];) and psychrophilic bacteria (Photobacterium, Psychromonas, and Shewanella [6, 68, 69, 141, 155];). The genomic adaptations of these microorganisms to the deep ocean or high hydrostatic pressure have not been fully explored (e.g. reviewed in $[67,100,106,122])$. Thus far the genome characteristics of only one experimentallyconfirmed obligately psychropiezophilic bacterial species, Shewanella benthica $[68,155]$, and one species of obligately thermopiezophilic archaeon, Pyrococcus yayanosii [58], have been described.
Most known psychropiezophilic strains belong to phylogenetically narrow lineages of Gammaproteobacteria, including members of the Colwellia, Shewanella, Moritella, Photobacterium, and Psychromonas (reviewed in $[56,98])$. The genus Colwellia contains some of the most psychrophilic and piezophilic species currently known. Members of this genus are heterotrophic and facultatively anaerobic [16]. This genus has been of recent interest because of its association with the Deepwater Horizon oil spill, where members of the Colwellia became some of the most abundant taxa present because of their ability to degrade hydrocarbons [60, 88, 117]. Although Colwellia do not appear to be abundant members of deep-ocean or hadal (typically < 1\%; e.g. [39, 107, 133]) communities, they can become dominant members under mesocosm conditions [15, 49, 109]. At least four piezophiles have been successfully isolated and described from this genus. The first known obligate psychropiezophile, originally designated Colwellia sp. MT41, was isolated from the amphipod Hirondellea gigas from the Mariana Trench at a depth of $10,476 \mathrm{~m}$ [151]. Strain MT41 shows optimum growth at 103 Megapascals (MPa) and does not grow at a pressure below $35 \mathrm{MPa}$, approximately the pressure at average ocean depths $[28$, 150, 151]. Recently, Colwellia marinimaniae MTCD1, the most piezophilic microbe known to date, was isolated from an amphipod from the Mariana Trench [62]. This strain displays an optimum growth pressure of 120 $\mathrm{MPa}$ and a growth range from 80 to $140 \mathrm{MPa}$, higher than the pressure found at full ocean depth. Based on 16S rRNA gene similarity both strains MT41 and MTCD1 were determined to belong to the species Colwellia marinimaniae [62]. Other psychropiezophiles within the genus include $C$. hadaliensis [32] and $C$. piezophila [97], isolated from the Puerto Rico and Japan trenches, respectively. While the growth characteristics and fatty acid profiles of these piezophilic species of Colwellia have been reported, other adaptations of these strains for dealing with high hydrostatic pressure and deep-ocean environmental conditions have not been investigated in great detail.

In this study, we compared the genomes of members of the Colwellia to identify attributes that confer adaptation to the deep ocean. We report the genome sequences of three obligately piezophilic Colwellia; Colwellia marinimaniae MT41, C. marinimaniae MTCD1, and a new isolate obtained from sediment in the Tonga Trench, Colwellia sp. TT2012. We compared these genomes, along with the publicly-available genome of C. piezophila ATCC BAA-637 (isolated as strain Y223G [97];), against three piezosensitive strains of $C$. psychrerythraea. The piezosensitive strains include the most well-studied member of the Colwellia, C. psychrerythraea $34 \mathrm{H}$, a psychrophile isolated from Arctic ocean 
sediments [53] whose adaptations to low temperature have been investigated at multiple levels (e.g. [87, 121]), including with genomics [91]. The two other comparison strains are C. psychrerythraea GAB14E and ND2E, obtained from the Great Australian Bight at a depth of $1472 \mathrm{~m}$ and the Mediterranean Sea from $495 \mathrm{~m}$, respectively (Fig. 1a [134];). While the C. psychrerythraea strains share 99\% identical $16 \mathrm{~S}$ rRNA sequences, they have very divergent average nucleotide identities (ANI [134];). Because low temperatures and high pressures have similar effects on biochemical processes, these three microbes were selected as comparison strains because they all show growth at low temperatures, reducing the impact of temperature as a confounding factor. Through the comparison of these seven strains depth and pressure-associated shifts were identified in protein amino acid distributions and isoelectric points, as well as in gene abundances, including the discovery of piezophile-specific genes.

\section{Results}

\section{General characteristics}

We first evaluated the influence of high hydrostatic pressure on the growth of the seven strains of Colwellia. The pressure-dependent growth characteristics of Colwellia marinimaniae MT41, C. marinimaniae MTCD1, and C. piezophila have been previously reported, showing growth optima at $103 \mathrm{MPa}$ [28, 150], $120 \mathrm{MPa}$ [62], and $60 \mathrm{MPa}$ [97], respectively. Colwellia sp. TT2012 is obligately piezophilic, showing growth at 84 and $96 \mathrm{MPa}$ but not at atmospheric pressure. Prior to further growth rate analyses strain TT2012 was lost following cryopreservation. Therefore, we tentatively report the optimum growth pressure in this manuscript as $84 \mathrm{MPa}$ as this was the original pressure of isolation. The three C. psychrerythraea strains displayed different growth patterns from one another, but similarly all grew at atmospheric pressure yet showed no growth at a pressure of $40 \mathrm{MPa}$ after 10 days regardless of temperature $\left(4{ }^{\circ} \mathrm{C}\right.$ or $16^{\circ} \mathrm{C}$; Supplementary Fig. 1). Based on these growth characteristics, we classified the microbes as either piezophilic ( $C$. marinimaniae MT41, C. marinimaniae MTCD1, Colwellia sp. TT2012, and C. piezophila) or piezosensitive (C. psychrerythraea strains 34H, GAB14E, and ND2E). These terms are used to describe these groupings for the remainder of the manuscript.

To identify genomic attributes that facilitate growth at high pressure in the deep sea, we compared the genomes of the piezophilic and piezosensitive strains (Table 1). We report here for the first time the genome sequences of Colwellia marinimaniae MT41, C. marinimaniae MTCD1, and Colwellia sp. TT2012. The remaining genomes are either publicly available (C. piezophila, [63]) or have been previously reported (strain $34 \mathrm{H}$, [91]; strains ND2E and GAB14E, [134]). The piezophiles are more closely related to one another than to the piezosensitive strains based on a whole genome marker tree and average nucleotide identity (Fig. 1). This is also true when the strains are compared using a ribosomal $16 \mathrm{~S}$ RNA gene phylogenetic tree (Supplementary Fig. 2). Colwellia marinimaniae MT41, C. marinimaniae MTCD1, and Colwellia sp. TT2012 share approximately 96\% 16S rRNA gene sequence similarity and formed a monophyletic clade with an isolate from the Kermadec Trench. Despite being isolated 34 years apart, strains MT41 and MTCD1 share greater than 99\% 16S rRNA gene sequence similarity and ANI. In contrast, the ANI of these strains are only $95 \%$ similar to TT2012, indicating that TT2012 likely represents a distinct species. C. piezophila does not appear to belong to this $16 \mathrm{~S}$ rRNA gene tree piezophile-only monophyletic clade (Supplementary Fig. 2). Despite showing greater than 98\% 16S rRNA gene sequence similarity, the ANI of C. psychrerythraea strains $34 \mathrm{H}, \mathrm{GAB} 14 \mathrm{E}$, and ND2E is less than $90 \%$, indicating that they have highly variable genome sequences.

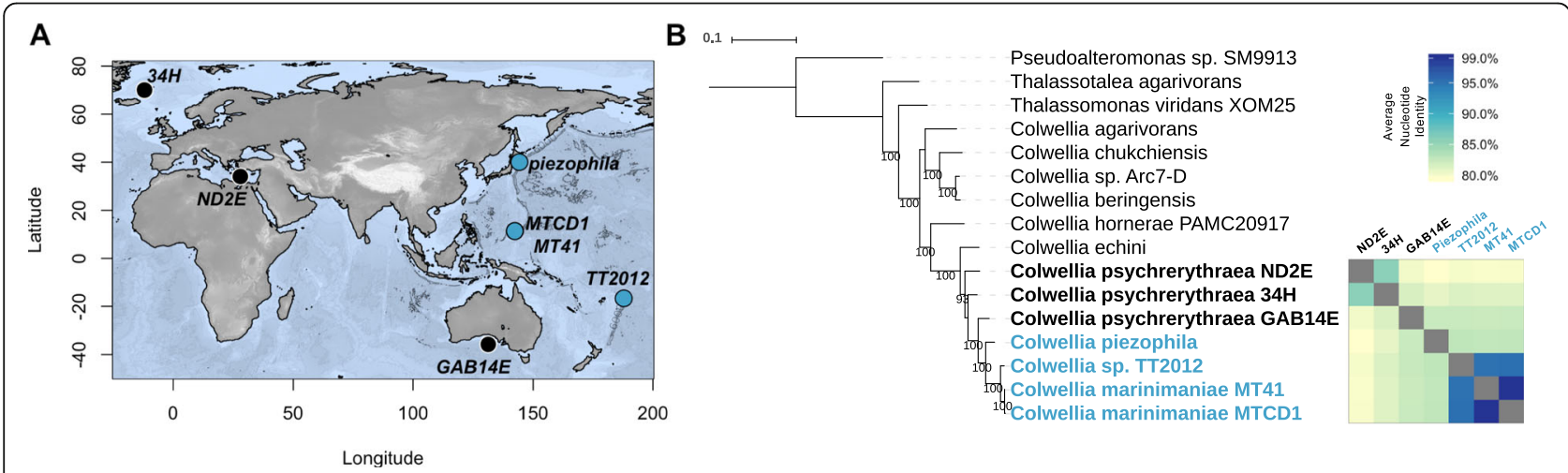

Fig. 1 a Approximate sample collection locations for the Colwellia strains compared in this study. The map was created using the R package marmap [104]. b Whole genome phylogenetic tree and shared average nucleotide identities among the seven strains of interest 


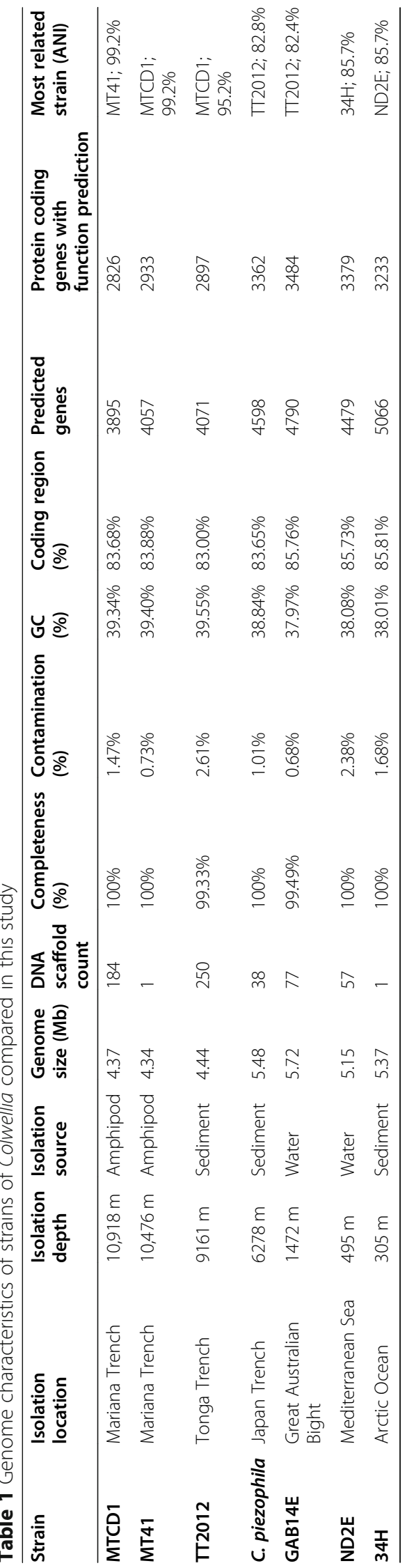




\section{GC content and amino acid features}

We first compared general genomic attributes of the piezophilic and piezosensitive strains, including genome size, GC content, isoelectric point, and amino acid distribution. Genome sizes ranged between 4.3 and 5.7 Mbp in size (Table 1). The three piezophiles isolated from the deepest depths (strains MT41, MTCD1, TT2012) have smaller genomes than the piezosensitive strains (T-test, $p<.031$ ), but no correlation between genome size and optimum growth pressure was found when considering C. piezophila and other members of the Colwellia (Supplementary Fig. 3). Coding density is lower in the piezophilic Colwellia. This is true even when including all sequenced members of the Colwellia (T-test, $p<.01$ ). GC content ranged between $\sim 38$ and $39 \%$, with slightly higher GC present in the piezophiles. This is also true when compared with other Colwellia strains with the exception of C. chukchiensis (Supplementary Fig. 3; T-test, $p<.08)$. However, when examining members of the genera Colwellia, Psychromonas, and Shewanella, no correlation was apparent between \% GC and growth pressure (Supplementary Fig. 4). No correlation was found between optimum growth pressure and \% GC within full length 16S rRNA genes in the Colwellia.

Next, we evaluated the isoelectric point distributions of the Colwellia proteomes. Both piezophilic and piezosensitive strains show a similar bimodal distribution of protein isoelectric points. However, the piezophiles have a higher number of basic proteins (Fig. 2; T-test, $p<.01$ ). This shift is also seen when comparing within a broader number of Colwellia ( $\mathrm{T}$-test, $\mathrm{p}<.01$ ) with the exception of C. chukchiensis (Supplementary Fig. 4). Piezophilic strains within the genera Psychromonas and Shewanella also show a higher number of basic proteins compared to their piezosensitive counterparts (Supplementary Fig. 4; T-test, Psychromonas, $p<.03$; T-test, Shewanella, clade $3, p<.34)$, with obligate piezophiles such as Shewanella benthica KT99, Psychromonas sp. CNPT3, and an uncultured Psychromonas single-amplified genome from a hadal amphipod [72] having dramatically more basic proteins. GC content or optimum growth temperature does not appear to be responsible for this shift in pI bias, even when taking into account withingenus phylogenetic clades (Supplementary Fig. 4, Supplementary Fig. 5).

Comparisons of amino acid abundances within conserved, orthologous proteins showed that certain amino acids are more abundant in the piezophilic proteins when compared to those in C. psychrerythraea $34 \mathrm{H}$ (Fig. 2 ). Amino acids that are specifically enriched in the piezophiles included tryptophan (W), tyrosine (Y), leucine $(\mathrm{L})$, phenylalanine $(\mathrm{F})$, histidine $(\mathrm{H})$, and methionine (M). In contrast, amino acids enriched in the piezosensitive strain included glutamic acid (E), aspartic acid (D), asparagine $(\mathrm{N})$, and serine (S). Specific amino acid asymmetrical substitutions in which one amino acid consistently replaced another, including substitutions that were also conserved in comparisons within members of the Shewanella, from piezosensitive to piezophilic amino acid were: glutamic acid $\rightarrow$ alanine $(\mathrm{A})$, proline $(\mathrm{P}) \rightarrow$ alanine, threonine $(\mathrm{T}) \rightarrow$ isoleucine $(\mathrm{I})$, valine $(\mathrm{V}) \rightarrow$ isoleucine (I), glutamic acid $\rightarrow$ lysine $(\mathrm{K})$, asparagine $(\mathrm{N}) \rightarrow$ lysine, glutamic acid $\rightarrow$ glutamine (Q; Fig. 2). Further asymmetrical substitutions specific to the genus Colwellia include, from non-piezophile to piezophile, aspartic acid $\rightarrow$ alanine, glycine $(G) \rightarrow$ alanine, serine $\rightarrow$ alanine, asparagine $\rightarrow$ histidine, valine $\rightarrow$ leucine, and glutamic acid $\rightarrow$ threonine.

\section{Gene differences}

We compared the predicted gene complements of the piezophilic and piezosensitive strains. When comparing relative abundances of clusters of orthologous genes (COGs; Fig. 3), piezophilic Colwellia have a higher percentage of genes for replication/recombination/repair (Category L), cell wall/membrane biogenesis (Category $\mathrm{M})$, cell motility (Category $\mathrm{N}$ ), extracellular structures (Category W), and translation and ribosomal structure (Category J). The piezosensitive strains have higher percentages of genes for transcription (Category K), secondary metabolite biosynthesis/transport/metabolism (Category Q), and general function prediction (Category $\mathrm{R})$. Transposable elements are notably more abundant in the piezophiles, with the exception of $C$. piezophila, having almost twice as many transposases as their piezosensitive counterparts (Fig. 3). Toxin-antitoxin genes are also enriched in the piezophiles, with piezophilic strains containing 24-33 toxin-antitoxin genes while the piezosensitive Colwellia have 9-18 copies. We found that strain MT41 and C. psychrerythraea $34 \mathrm{H}$ have approximately 11 and 9 genomic islands (GIs), respectively, as determined using Island Viewer [13]. We do not report the total number of GIs in the other strains because the fragmentation of their genomes likely leads to GI misidentification. Of the 11,343 unique genes identified at $70 \%$ similarity using Roary [103], 2035 genes were shared amongst all seven strains. Only 45 genes were present in all four piezophilic Colwellia but none of the piezosensitive strains (Fig. 3; Supplementary Table 1).

All of the strains analyzed are heterotrophic. However, potential differences in carbon metabolism exist (Fig. 3). Genes for sarcosine oxidase ( $\operatorname{sox} B D A G$ ), which function in the catabolism of glycine betaine in Colwellia [24], are present in $34 \mathrm{H}$ and ND2E but not in the piezophiles. Transporters and permeases for putrescine are enriched in $34 \mathrm{H}$ and GAB14E, strains where putrescine has been experimentally shown to be used as a sole carbon source [134]. In contrast, we identified genes involved in chitin 

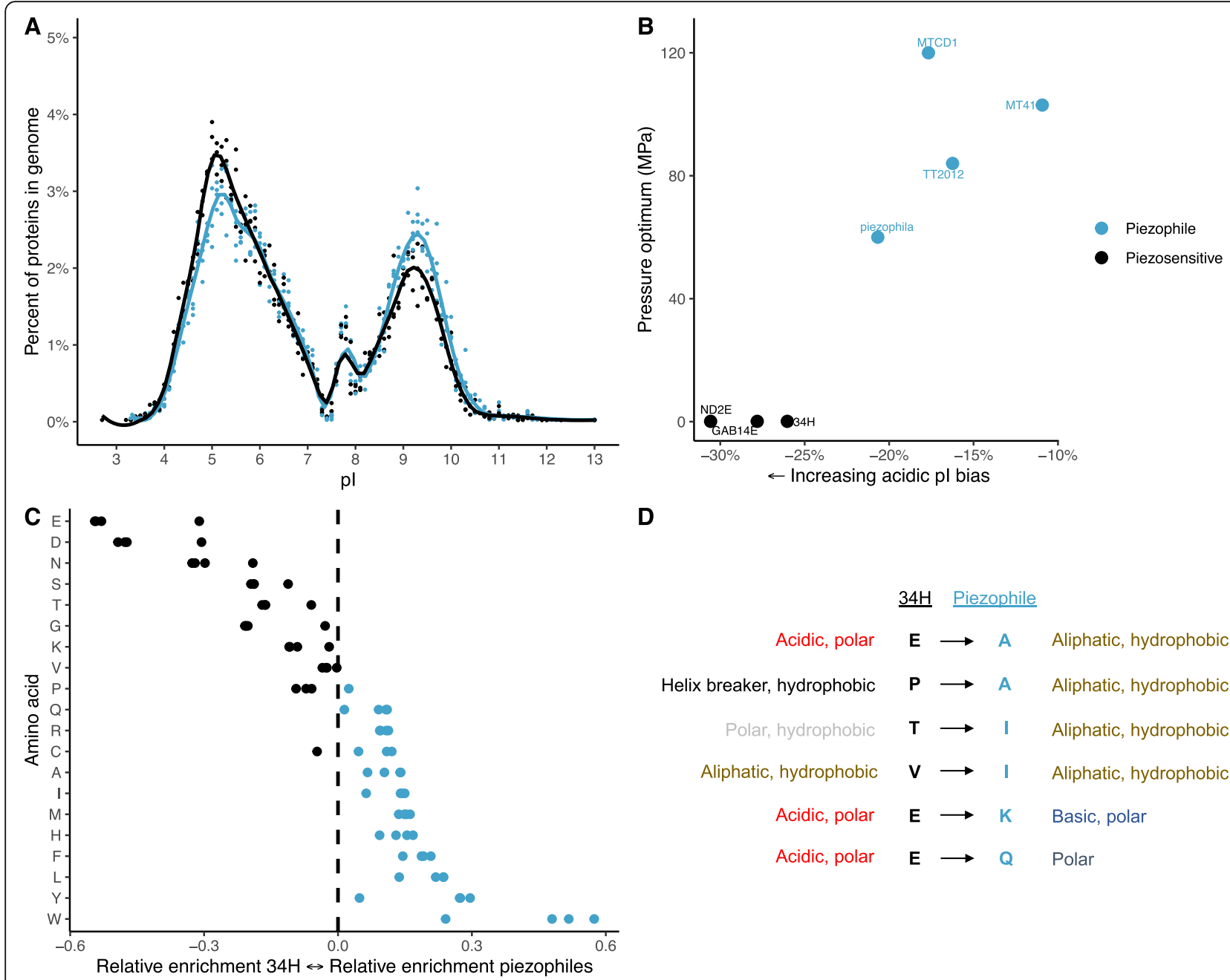

D

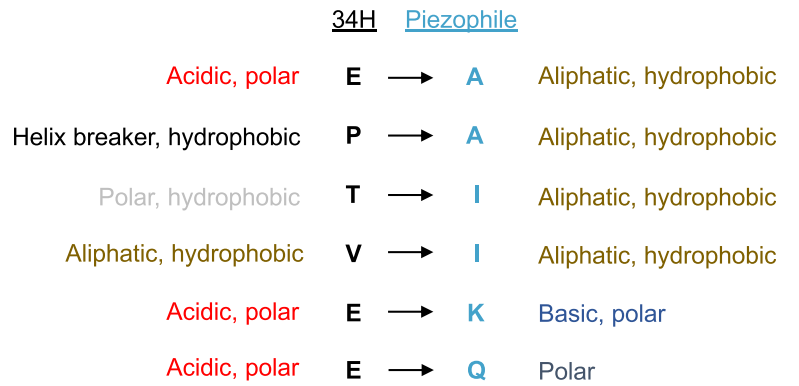

Fig. 2 a; Isoelectric point distribution of proteins within piezophilic (blue points) or piezosensitive (black) strains, with an average line of fit within each group. $\mathbf{b}$; Isoelectric point protein bias within each strain as a function of their growth pressure. $\mathbf{c}$; Asymmetry index values indicating preference of amino acids in the piezophiles or C. psychrerythraea $34 \mathrm{H}$ within orthologous proteins present in all strains. d; Specific amino acid substitutions from C. psychrerythraea $34 \mathrm{H}$ to the piezophiles within orthologous proteins. The substitutions shown were also identified within comparisons between piezophilic and piezosensitive Shewanella

degradation, such as a chitin binding protein and chitinase (family 10 and 18), in the piezophiles and GAB14E but not in the other piezosensitive strains.

Members of the Colwellia are facultative anaerobes capable of respiration and fermentation. While all the Colwellia compared here use both the $\operatorname{rnf}(\operatorname{rnf} A B C D G E)$ and $\mathrm{Na}^{+}$-nqr (nqrABCDEF) respiratory complexes, the NADH dehydrogenase I complex (nuoABCEFGHIJKLMN) is only present in the three hadal piezophiles. These genes show similarity to those in the piezophiles Shewanella benthica and S. violacea and to metagenomic sequences from hadal sediments [108]. While all seven strains have genes for respiration via nitrate reduction (napCBADFE), genes for dissimilatory nitrite reduction (nirSCFNTB) are only present in
C. psychrerythraea strains $34 \mathrm{H}$ and ND2E. The dissimilatory nitrite reduction gene nirK is present in C. piezophila, although this strain was shown to reduce nitrate but not nitrite [97]. The gene cluster for nitrous oxide reduction, nosRZDFYL, is present in strains $34 \mathrm{H}$, ND2E, and C. piezophila. This operon is flanked by conserved regions found in the other strains, suggesting an insertion or deletion event. Furthermore, the capacity for trimethylamine-N-oxide (TMAO) reduction using torSTRECAD is present in strains $34 \mathrm{H}$ and ND2E but not in any of the piezophiles.

The seven strains of Colwellia compared are psychrophilic or psychrotolerant and have adaptations to low temperatures. For example, all contain $p f a A B C D$ to produce polyunsaturated fatty acids to counteract decreases 


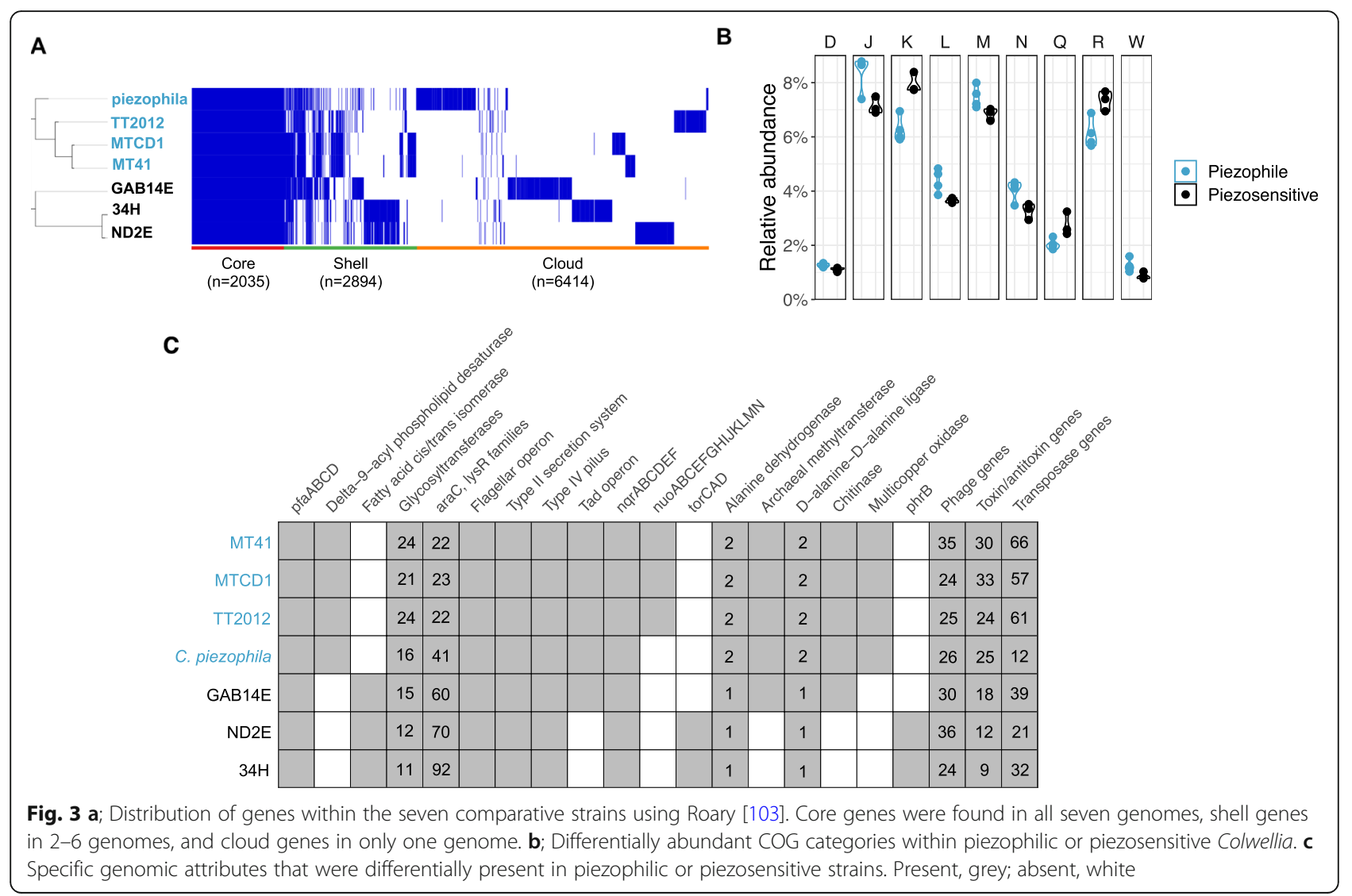

in membrane fluidity because of low temperatures. In the case of the deep-sea Colwellia this system will also optimize membrane phospholipid physical state at high pressure. However, a number of genes involved in membrane adaptation are differentially present among the two Colwellia groups. All piezophilic Colwellia have genes encoding delta-9 acyl-phospholipid desaturase, another enzyme promoting unsaturated fatty acid synthesis by introducing double bonds directly into membrane phospholipid saturated fatty acids. In contrast, a fatty acid cis/trans isomerase that alters the ratio of cis- and trans- phospholipids by isomerizing -cis to -trans double bonds, is encoded within all piezosensitive Colwellia but is notably absent in the piezophilic Colwellia. Furthermore, the piezophilic strains encode almost twice as many glycosyltranferases, enzymes involved in extracellular polysaccharide synthesis.

Stress-response genes are also differentially present in the genomes. Deoxyribopyrimidine photolyase (DNA photolyase; $p h r B$ ), which is involved in repairing DNA damaged by ultraviolet light, is found in strains $34 \mathrm{H}$ and ND2E but notably absent in all piezophilic Colwellia. Both piezophilic and piezosensitive strains contain superoxide dismutase and catalase for responding to oxidative stress. The genes $a r a C$ and $l y s R$, whose products control the expression of a variety of stress response systems, are more abundant in the piezosensitive Colwellia. The piezophilic Colwellia are distinct in having multicopper oxidases and copper chaperones for coping with heavy metal damage and maintaining copper homeostasis. Phenotypic analysis of the Colwellia showed that the piezophiles appear more resistant to copper exposure compared to their non-piezophilic counterparts (Supplementary Fig. 6). Some of the genes which putatively confer heavy metal resistance are similar to other piezophiles and are located near genomic islands or other horizontally transferred elements, consistent with the hypothesis that heavy metal genes can be horizontally transferred (e.g. [20, 96, 101]).

We identified other unique genes that differ not only between Colwellia strains but show biased distributions towards additional piezophilic microbes and deep-ocean metagenomic datasets (Table 2 [34, 51, 108, 137];). For example, a putative S-adenosyl-l-methionine (SAM) dependent methyltransferase (pfam13659) is present in the piezophiles and strain GAB14E. This protein is similar to those present in bacterial and archaeal piezophiles, including members of the genera Colwellia, Shewanella, Moritella, Psychromonas, Methanocaldococcus, Thermococcus, and Pyrococcus. The related methyltransferase 
Table 2 Genes identified in piezophilic Colwellia but not the piezosensitive strains and which show a biased presence within other known piezophilic microbes and deep-ocean datasets. The gene description describes more specific annotations for select genes in each genomic region identified

\begin{tabular}{|c|c|c|c|c|}
\hline IMG Gene ID MT41 & Start MT41 (bp) & End MT41 (bp) & Similar to: & Gene description(s) \\
\hline $\begin{array}{l}2501712773- \\
2501712774\end{array}$ & 738561 & 741622 & $\begin{array}{l}\text { P. hadalis, S. benthica, S. violacea, M. yayanosii, } \\
\text { Moritella sp. PE36, [108], [51], [137] }\end{array}$ & Lipoprotein \\
\hline 2501712781 & 748798 & 749364 & S. benthica, [137], [34] & CDP-alcohol phosphatidyltransferase \\
\hline 2501712785 & 751307 & 751420 & P. hadalis, [108] & Chemotaxis-related \\
\hline $\begin{array}{l}2501713024- \\
2501713025\end{array}$ & 1002,24 & 1003568 & M. yayanosii, Moritella sp. PE36, [137], [34] & Hypothetical, copper chaperone \\
\hline $\begin{array}{l}2501713028- \\
2501713043\end{array}$ & 1004921 & 1020893 & $\begin{array}{l}\text { P. hadalis, S. benthica, S. violacea, M. yayanosii, } \\
\text { Moritella sp. PE36, [51], [137] }\end{array}$ & Tad pilus \\
\hline 2501713628 & 1635614 & 1636453 & $\begin{array}{l}\text { P. hadalis, S. benthica, S. violacea, M. yayanosii, } \\
\text { Moritella sp. PE36, piezophilic archaea, [51], [137] }\end{array}$ & SAM-dependent methyltransferase \\
\hline 2501713976 & 1995082 & 1995321 & S. benthica & RelE toxin \\
\hline 2501714033 & 2052,42 & 2052666 & S. benthica & Hypothetical \\
\hline 2501714084 & 2101280 & 2101915 & $\begin{array}{l}\text { P. hadalis, S. benthica, S. violacea, M. yayanosii, } \\
\text { Moritella sp. PE36, [137] }\end{array}$ & Hypothetical \\
\hline $\begin{array}{l}2501714124- \\
2501714126\end{array}$ & 2137413 & 2141565 & P. hadalis, S. benthica, M. yayanosii, [137], [34] & D-alanine-D-alanine ligase \\
\hline $\begin{array}{l}2501714471- \\
2501714485\end{array}$ & 2514635 & 2530350 & S. benthica, S. violacea, [108] & NADH dehydrogenase \\
\hline 2501714619 & 2663589 & 2663918 & S. benthica, [108], [137] & Heat shock protein \\
\hline 2501714669 & 2714988 & 2715770 & M. yayanosii, Moritella sp. PE36, SAR324, [108], [137] & Hydrolase \\
\hline 2501715698 & 3869630 & 3871057 & $\begin{array}{l}\text { Photobacterium profundum SS9, S. benthica, } \\
\text { M. yayanosii, Moritella sp. PE36, [108], [137] }\end{array}$ & Alanine dehydrogenase \\
\hline 2501715722 & 3894109 & 3895707 & P. hadalis, [137] & Arylsulfatase \\
\hline $\begin{array}{l}2501715931- \\
2501715932\end{array}$ & 4122279 & 4122819 & S. benthica, M. yayanosii & RelE toxin \\
\hline $\begin{array}{l}2501716002- \\
2501716003\end{array}$ & 4182966 & 4183371 & S. benthica, M. yayanosii, [137] & YoeB toxin \\
\hline
\end{tabular}

isolated from Pyrococcus abysii (39\% similar to MT41 protein) functions in tRNA modification [47]. Piezophilic Colwellia have two copies of $\mathrm{d}$-alanine-d-alanine ligase (pfam07478), a gene which may be involved in peptidoglycan synthesis. Unlike the situation in piezophilic Shewanella [155], this gene is not present near flagellar assembly components. While all strains have operons for a Type II secretion system and a Type IV pilus, a tad pilus involved in adhesion is found only in the piezophiles and related to that in Shewanella violacea. This operon is also found in GAB14E; however, this strain lacks a number of putative tadE-like genes that are present in the piezophile operons. Two alanine dehydrogenases are also present in the piezophilic strains while only one is present in the piezosensitive members. The piezophile-specific dehydrogenase (pfam05222) is thought to catalyze the NAD-dependent reversible amination of pyruvate to alanine. It is similar to a dehydrogenase present in other piezophilic species, including Shewanella benthica, Moritella yayanosii, Photobacterium profundum SS9, and binned genomes from a deep subsea aquifer [137] and trench sediments [108].
A number of the genes specific to piezophiles are present near one another, rather than individually spread throughout the genome (Table 2). Many of these genes are near variable regions containing genomic islands, phage genes, transposases, and toxin-antitoxin system genes (Supplementary Fig. 7). For example, the dalanine-d-alanine ligase in strain MT41 is next to two putative genomic island regions, one of which is different than that present in strain TT2012 (Fig. 4). Because genomic islands are identified based on nucleotide bias across the genome and the Colwellia sp. TT2012 genome is fragmented into short contigs, the lack of predicted genomic islands does not preclude their presence. In the piezophile Moritella yayanosii this gene is near a gene encoding a predicted phage integrase protein, while in Shewanella benthica KT99 it is present in a flagellar operon that also contains a transposase embedded within it. Similarly, the piezophile-specific alanine dehydrogenase is present near a number of phage and toxin/antitoxin genes and downstream from a genomic island. In strain TT2012, this gene is in the middle of a 


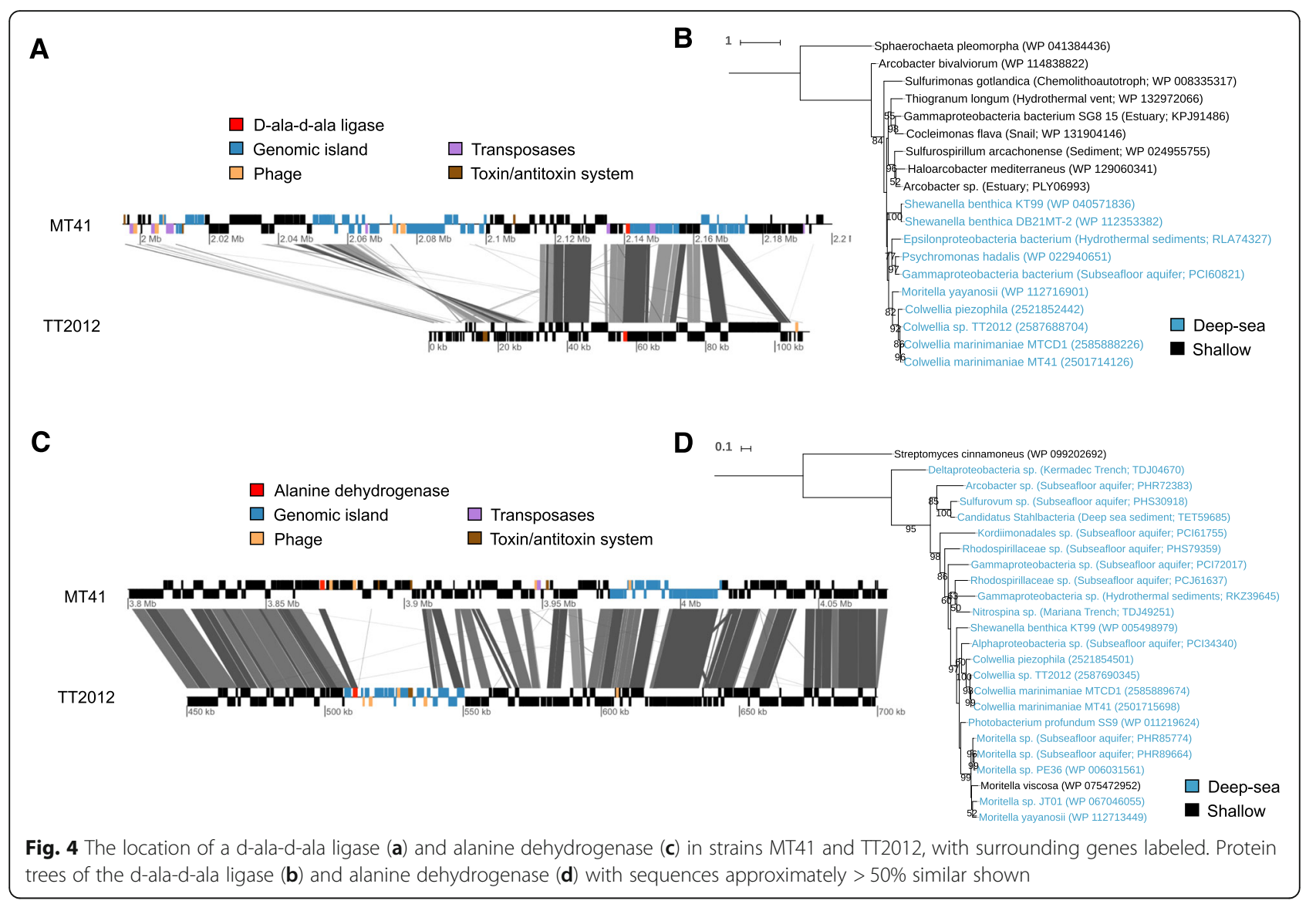

putative genomic island (Fig. 4), while in Photobacterium profundum SS9 it is flanked on one side by a transposase. Some of the genes present in these variable regions, when not specific to piezophiles, display low similarity to members of the genus Vibrio. The similarity of variable genes within Colwellia to species of Vibrio has been previously noted [24]. Horizontal gene transfer has been shown to be important in the evolution of Vibrio species [40].

\section{Discussion}

In this study we compared the genomes of members of piezophilic Colwellia - including the most high pressure-adapted species known to date - with their piezosensitive counterparts to search for features that could confer adaptation to the deep sea. These microbes were isolated from surface and bathyal waters to abyssal and hadal depths. Both 16S rRNA gene sequence-based phylogenetic analyses and phylogenomic analyses indicate that the piezophilic Colwellia are closely related. While the piezophiles appear to form a single cluster based on the phylogenomic tree, in the 16S rRNA gene phylogenetic tree C. piezophila appears basal to not only the piezophiles but also a clade that includes piezosensitive lineages. Therefore, it is possible that piezophily has evolved multiple times within the Colwellia. Further whole genome sequencing will be needed to determine if all piezophilic Colwellia form a single clade independent from other piezosensitive microbes as has been reported for Shewanella [6]. Piezophilic Colwellia have now been isolated from five different trenches, including the Mariana (strains MT41, MTCD1), Puerto Rico (C. hadaliensis), Japan (C. piezophila), Tonga (strain TT2012), and Kermadec (Bartlett laboratory unpublished [65, 66, 109]; ). Piezophilic members of the genus Colwellia are therefore widespread within deep-ocean and hadal environments.

While the piezophiles have lower coding density than their non-piezophilic counterparts, no correlation was found between genome size and optimum pressure of growth. This is in contrast to comparisons between shallow and deep pelagic datasets showing that deeper lineages appear to have larger genomes (e.g. $[14,39,61$, 135]). Instead, the three piezophiles with the deepest collection depths represented some of the smallest Colwellia genomes examined. One possibility is that these differences reflect different selective pressures operating within seawater, sediments and amphipods. It is remarkable that strain MT41 and MTCD1, two piezophiles isolated from amphipod material in the Mariana Trench 
34 years apart, share over 99\% ANI. Perhaps this reflects strong selection for a particular Colwellia strain within the microbiome of Mariana Trench Hirondellea gigas amphipods, such as that seen within symbionts of deepsea anglerfishes [9]. Their consistent isolation from amphipods (e.g. $[62,151])$ suggests that some members can be associated with hosts, and host-microbe relationships can lead to genome streamlining and smaller genome sizes [89]. Nearly all known piezophilic genera have been found in conjunction with hosts (e.g. [95]) and the microbial activity of the gut contents of deep-sea animals shows high levels of piezophily [131]. However, the genus Colwellia is not present in recognizable abundances within hadal amphipod metagenomes [154], their high \% GC is not indicative of an endosymbiont [89], and the obligate piezophile Colwellia sp. TT2012 was isolated from sediments rather than amphipods. An alternative hypothesis is that Colwellia may be undergoing genome reduction because of a specialized lifestyle within the deep sea, as hypothesized for some psychrophiles within sea ice [42]. Members of this genus may instead be isolated in conjunction with amphipods because of their ability to degrade nutrient-rich decaying amphipod material, for example using genes for chitin degradation. Colwellia may also be ingested by amphipods as a byproduct of the feeding of these deep-sea scavenging macrofauna because of the preference of Colwellia for nutrient-rich particulate organic material [15, 49, 107].

The isoelectric point ( $\mathrm{pI}$ ) distribution of proteins within a proteome can correlate with the ecological niche of an organism [59]. Here we found that piezophilic Colwellia have more basic proteins than their piezosensitive counterparts. This pattern is conserved in comparisons between piezophilic and piezosensitive members of the genera Shewanella and Psychromonas, indicating it is a property that may be widespread amongst piezophiles within the Gammaproteobacteria. Although intracellular microorganisms also have more basic proteomes than free-living species [59], this is associated with an AT base pair enrichment not present in the piezophilic Colwellia. A basic proteome may be the result of the accumulation of mutations [59], consistent with the low coding density and high numbers of transposable elements within the piezophiles. Alternatively, it could arise to help with charge balance within the cytoplasm, analogous to the role of the more acidic proteome of haloarchaea, which counters the high intracellular potassium ion levels present at high osmotic pressures [26], or the osmotic differences between freshwater and marine species [17]. The intracellular inorganic and organic solute levels within piezophiles are not well known, but could be important to the maintenance of macromolecule function at high pressure [81,
146, 147]. Among orthologous proteins piezophiles are also enriched in hydrophobic residues, including tryptophan, tyrosine, leucine, phenylalanine, histidine, and methionine. This finding has been noted in metagenomes from $4000 \mathrm{~m}$ [61] and may be important in maintaining protein structure against water penetration at high pressure [52, 125]. Specific amino acid substitutions where one amino acid is consistently replaced by another indicate that small nonpolar compounds (alanine, isoleucine), amine-containing polar compound (glutamine), and a positively charged basic compound (lysine) are selected for in piezophiles, while negatively charged acidic compounds (glutamate), polar compounds (threonine, asparagine), and non-polar compounds (valine, proline) are selected against. Similar shifts were also seen in Desulfovibrio piezophilus [113], although different amino acids were preferentially abundant in piezothermophilic archaea [33].

We identified a number of gene abundance characteristics that could confer adaptation to the deep ocean. Enrichments in COG J (translation), L (replication and repair), $M$ (cell wall/membrane biogenesis), and $\mathrm{N}$ (cell motility) appear enriched in the piezophiles. An enrichment of category $M$ and $L$ has previously been observed within deep ecotypes of Alteromonas [55]. The enrichment within the piezophiles of COG M is in part due to higher abundances of glycosyltransferases, which appear to correlate with depth within metagenome datasets [31]. Glycosyltransferases have been predicted to contribute to low temperature-adaptation [91] and could be more abundant in the psychropiezophiles because they are more stenothermic. In contrast, a fatty acid cis/trans isomerase was present only in the piezosensitive strains. The rapid cis-to-trans isomerization of unsaturated fatty acids via this isomerase has been observed in Pseudomonas putida $\mathrm{P} 8$ in response to changes in temperature and salinity [50, 76]. Furthermore, the COG category for transcription $(\mathrm{K})$ is significantly enriched in nonpiezophiles compared to piezophiles. This is in part due to an enrichment in the transcription factors AraC and LysR, which have a wide variety of regulatory functions including carbon metabolism and stress response [44, 80]. The enrichment of COG category $K$ in shallowwater organisms has been observed in the surface-water ecotype of Alteromonas macleodii [55]. These findings could reflect the adaptation of non-piezophilic shallowwater microbes to a more dynamic environment, such as rapid salinity or temperature shifts associated with seaice or surface seawater. In contrast, autochthonous, obligate deep-ocean microbes would not be expected to experience similar rates or magnitudes of these changes.

Other specific genes biased towards piezophiles within COG $M$ include delta-9 acyl-phospholipid desaturase and a CDP-alcohol phosphatidyltransferase. While the 
desaturase is upregulated at high pressure in Photobacterium profundum SS9 [18], this gene is present in other non-piezophilic strains of the Colwellia not examined here, indicating it may not be pressure-specific. An extra copy of d-alanine-d-alanine ligase is present in the piezophiles and may function in peptidoglycan biosynthesis. While this gene was reported within a flagellar operon in Shewanella benthica [155], in strain MT41 it is present next to a putative genomic island (Fig. 4). The non-piezophile-specific copy of $d$-alanine-d-alanine ligase is upregulated in the proteome of strain $34 \mathrm{H}$ after incubation at $-1{ }^{\circ} \mathrm{C}$ [99], perhaps reflecting a role in low temperature acclamation. Overall, the enrichment in piezophiles of genes involved in COG category $\mathrm{M}$ is consistent with a wealth of experimental evidence demonstrating that changes in membrane structure are critical for adapting to high hydrostatic pressure. Unsaturated fatty acids help maintain membrane structure under high pressure [2, 3, 21, 138, 149], with strain MT41 able to produce more than $15 \%$ of its total membrane fatty acids as docosahexaenoic acid (22:6 [30];).

Another adaptation associated with the membrane involves energetics and respiration. We identified an additional NADH ubiquinone oxidoreductase (nиo) gene cluster in a number of piezophiles. This unique NADH dehydrogenase, which translocates four protons per two electrons [111], may help with energy acquisition under in situ, high pressure conditions. We also identified an alanine dehydrogenase specific to the piezophiles that may function in the reversible amination of pyruvate to alanine coupled with the oxidation of NADH to NAD ${ }^{+}$. This may act as an adaptive strategy under inhibited respiratory conditions by maintaining $\mathrm{NADH} / \mathrm{NAD}^{+}$ homeostasis [57], such as during shifts to anoxic conditions $[41,54]$ or after exposure to physical stressors impeding electron flow. Alanine dehydrogenases in Listeria are insensitive to inactivation up to pressures of 550 $\mathrm{MPa}$ [123], transcriptionally upregulated in Desulfovibrio piezophilus at high pressure [113], and abundant in the proteomes of strain $34 \mathrm{H}$ at sub-zero temperatures [99]. We speculate that the piezophilic alanine dehydrogenase functions in $\mathrm{NADH} / \mathrm{NAD}^{+}$homeostasis under high hydrostatic pressure conditions. In contrast, we found that TMAO reductase (torECAD), which reduces TMAO to TMA, was not present in any of the piezophilic Colwellia. A similar finding has been noted in genomes of Psychromonas from the guts of hadal amphipods, where the lack of TMAO reductase was attributed to the preferential need for TMAO as a piezolyte in the host amphipod over its use as an electron acceptor by the microbe [153]. An alternative hypothesis is that TMAO is used by microbial piezophiles as a piezolyte as it is in deep-sea metazoans $[147,148]$. Finding differences in respiratory capacity within piezophiles is not unexpected.
Others have previously noted the influence of collection depth and pressure on the presence and regulation of respiratory membrane-bound cytochrome c oxidases and hydrogenases [22, 72, 92, 132, 140, 141, 144, 145, 153]. These changes could stem directly from pressure influences or from a greater reliance on the colonization of reduced oxygen niches associated with particles or animals $[15,109]$. This latter possibility could be facilitated by the tad pilus present in the piezophilic Colwellia $[112,115,136]$.

Horizontal gene transfer (HGT) can provide genetic material that enhances fitness in new environments. An experimental demonstration of this impact is the introduction of a DNA photolyase gene, missing in piezophilic Colwellia and other deep-sea species [31, 61, 67, 110], into the piezophile Photobacterium profundum SS9 to generate a UV resistant phenotype [70]. It is striking that many of the Colwellia genes most similar to those in other piezophiles appear in clusters within variable regions that include genomic islands, putative phage genes, transposases, and toxin-antitoxin systems. Despite their smaller genome sizes, laterally transferred elements such as transposase and toxin-antitoxin genes are more abundant in the piezophilic Colwellia examined here, consistent with their lower coding densities. Another notable feature of these variable regions is that they differ even between closely-related strains, such as between Colwellia marinimaniae MT41 and C. marinimaniae MTCD1.

Mobile genetic elements have been suggested to confer adaptations to extreme conditions (e.g. [5, 23, 43, 77, 84, 113]), such as in the known piezophile Photobacterium profundum SS9 [18]. Deep-sea specific toxin-antitoxin systems have been identified in members of the Shewanella [155] and have been shown to influence the growth of Pyrococcus yayanosii at different pressures [74, 75]. Mobile genetic elements may provide new metabolisms within strains of Colwellia psychrerythraea, including the transfer of sox genes involved in sarcosine metabolism $[24,134]$. Because of the similarity of many genomic island-associated genes in members of the piezophilic Colwellia to those in other gammaproteobacterial piezophiles, we suggest that HGT is a significant evolutionary process governing high pressure adaptation. Future studies should evaluate these regions and their associated genes for their importance in piezophily.

\section{Conclusions}

In this study we compared the genomes of piezophilic and piezosensitive Colwellia to identify adaptations to extreme deep-ocean conditions. Differences in amino acid composition, membrane and cell wall structure, respiratory capacity, tRNA modification, and complex organic carbon utilization appear to be important for life at hadal depths. It appears that adaptation to the deep- 
ocean therefore requires many changes throughout the cell (Fig. 5). Many piezophile-enriched genes are located near areas of genomic variability and could be shared among piezophiles by horizontal gene transfer. Some of the adaptations identified may not be for high pressure adaptation per se, but for lifestyles favored in hadal trenches such as affiliation with particulate organic carbon or animals. Comparative transcriptomics of these isolates will provide further insight into their adaptations to high hydrostatic pressure.

\section{Methods}

\section{Sample collection and high-pressure cultivation conditions}

Colwellia sp. TT2012 was isolated from sediments collected via gravity core in the Tonga Trench $\left(16^{\circ} 38.505^{\prime}\right.$

S, $172^{\circ} 12.001^{\prime}$ W) at a depth of $9161 \mathrm{~m}$ on September 2, 2012 aboard the $R / V$ Roger Revelle. Sediment from the upper three $\mathrm{cm}$ sediment depth horizon was mixed with filter-sterilized trench seawater and maintained at a pressure of $84 \mathrm{MPa}$ and $4{ }^{\circ} \mathrm{C}$. A subset of this material was inoculated into ZoBell 2216 Marine Medium (BD Difco, Thermo Fisher, Waltham, MA, USA) under the same pressure and temperature conditions. Colwellia sp. TT2012 was eventually isolated as a pure culture following a number of dilution to extinction inoculations.
The isolation of both strains of Colwellia marinimaniae have been previously described. Colwellia marinimaniae MTCD1was isolated from amphipods at a depth of 10,918 $\mathrm{m}$ in the Challenger Deep [62]. Colwellia marinimaniae MT41 was also isolated from amphipods at a depth of $10,476 \mathrm{~m}$ [151]. Both strains were maintained in pressurizable polyethylene transfer pipette bulbs (Samco Scientific, USA) with Zobell 2216 Marine Medium broth at $4{ }^{\circ} \mathrm{C}$ and high pressure prior to sequencing.

\section{Pressure sensitivity and heavy metal sensitivity testing}

The growth of the strains was evaluated under different pressure and temperature conditions. Cultures of Colwellia strains $34 \mathrm{H}, \mathrm{GAB} 14 \mathrm{E}$, and ND2E were incubated in Zobell 2216 marine medium supplemented with 100 $\mathrm{mM}$ HEPES and $20 \mathrm{mM}$ glucose at $4{ }^{\circ} \mathrm{C}$. Growth under high hydrostatic pressure was evaluated by incubating cultures at $20 \mathrm{MPa}$ increments between $0.1-80 \mathrm{MPa}$ at $4{ }^{\circ} \mathrm{C}$ and $16^{\circ} \mathrm{C}$ in triplicate. The OD600 was measured every 2.5 days for 10 days. Growth rates of Colwellia sp. TT2012 were conducted at $0.1,84$, and $96 \mathrm{MPa}$ at $4{ }^{\circ} \mathrm{C}$. Copper sensitivity tests were also performed on the piezophilic (strains MT41, MTCD1, and TT2012) and non-piezophilic Colwellia strains (strains 34H, GAB14E, ND2E). Copper (II) chloride dihydrate in concentrations ranging from 0 to $1.5 \mathrm{mM}$ in $0.3 \mathrm{mM}$ increments were

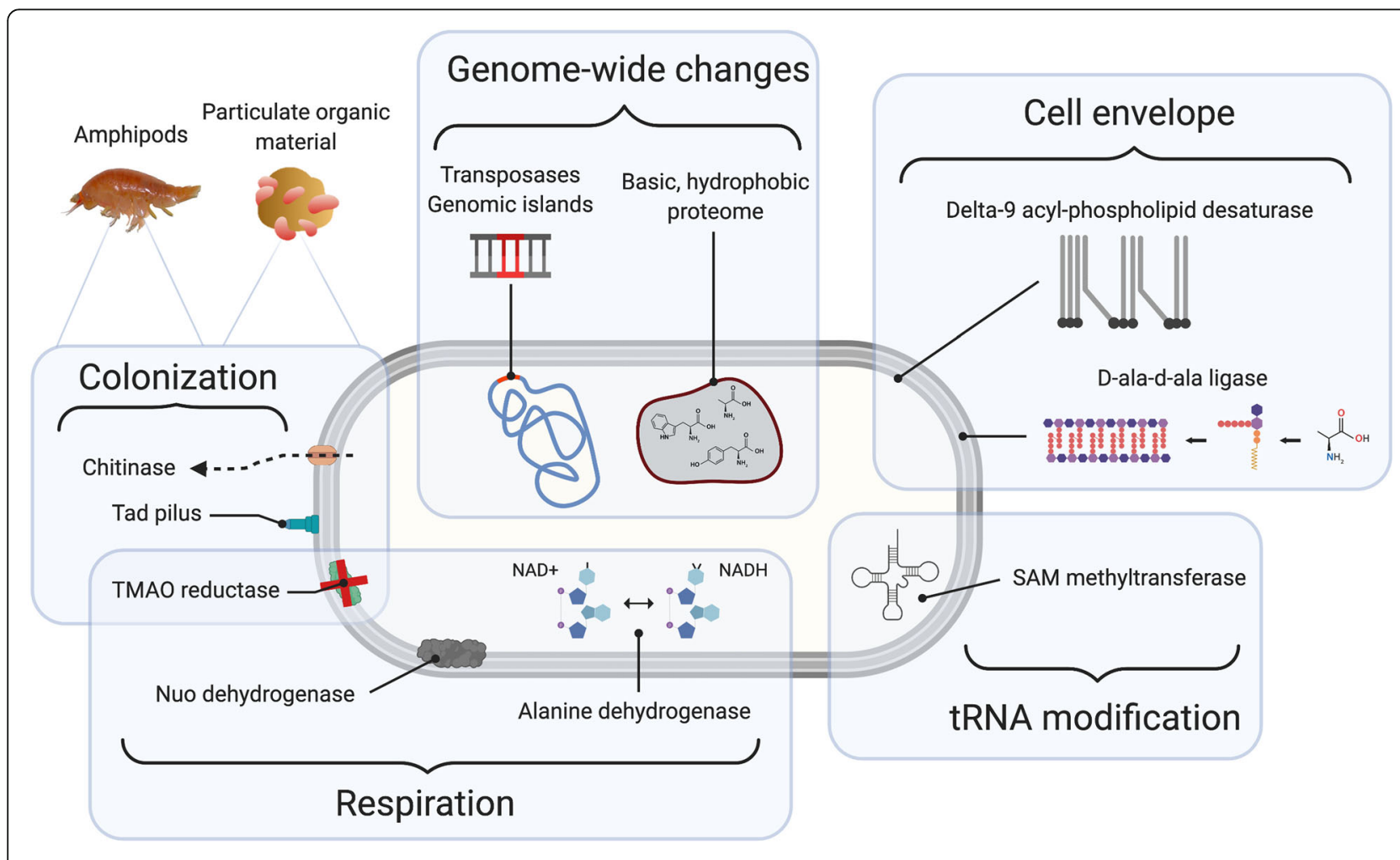

Fig. 5 A cell schematic highlighting adaptations within piezophilic Colwellia identified in this study. The figure was created using Biorender.com 
added to inoculated 2216 media and the cultures were incubated at $4{ }^{\circ} \mathrm{C}$ for $1-4$ weeks with weekly inspection.

\section{Genome sequencing and assembly}

Genomic DNA from C. marinimaniae MTCD1 was extracted from $100 \mathrm{~mL}$ of liquid culture after 4 weeks of incubation at $110 \mathrm{MPa}$. DNA was isolated using the MoBio Ultraclean Microbial DNA Isolation Kit (Mo-Bio, USA). Genomic DNA was obtained from Colwellia sp. TT2012 after growth at $84 \mathrm{MPa}$ and $4{ }^{\circ} \mathrm{C}$ for 3 weeks. Cells were filtered onto a 0.22 um Millipore Sterivex filter cartridge (Fischer Scientific, USA) and first subjected to a lysis buffer $(50 \mathrm{mM}$ Tris- $\mathrm{HCl}$ at $\mathrm{pH} 8.3,40 \mathrm{mM}$ EDTA at pH 8.0, 0.75 M sucrose) and R1804M ReadyLyse lysozyme solution (Illumina, USA). After 15 min of incubation at $37^{\circ} \mathrm{C}$, proteinase $\mathrm{K}$ and sodium dodecyl sulfate were added to a final concentration of $0.5 \mathrm{mg} / \mathrm{ml}$ and $1 \%$ respectively. The mixture was then incubated at $55^{\circ} \mathrm{C}$ for $25 \mathrm{~min}$, followed by $70^{\circ} \mathrm{C}$ for $5 \mathrm{~min}$. The lysate was treated two times with phenol-chloroform-isoamyl alcohol (24:24:1) and chloroform:isoamyl alcohol (24:1) and further purified using a Mo-Bio Utraclean DNA Isolation Kit spin column. The genomes of C. marinimaniae and Colwellia sp. TT2012 were sequenced at the Institute for Genomic Medicine (IGM) at UCSD using the MiSeq sequencing platform (Illumina, San Diego). The raw forward and reverse reads were merged using FLASH version 1.2.10 [83] and assembled with SPAdes version 3.1.0 [10].

The genome of strain MT41 was sequenced to closure by whole random shotgun sequencing. Briefly, one small insert plasmid library $(2-3 \mathrm{~kb})$ and one medium insert plasmid library $(10-15 \mathrm{~kb})$ were constructed by random nebulization and cloning of genomic DNA. The sequences were assembled using the TIGR Assembler [127]. All sequence and physical gaps were closed by editing the ends of sequence traces, primer walking on plasmid clones, and combinatorial PCR followed by sequencing of the PCR product.

\section{Genomic completeness, phylogenetic analysis, and annotation}

The genomes were evaluated for their completeness and phylogenetic relationships. Genome completeness and contamination was estimated using CheckM [105]. A whole-genome phylogenetic tree was built using RAxML [126] on the CIPRES science gateway [93] using the single-copy marker genes identified within CheckM. Ribosomal 16S RNA gene trees were also built by aligning sequences using the SINA Aligner [114] and built using RAxML All trees were visualized using the Interactive Tree of Life [73]. Genomes were annotated using the Integrated Microbial Genomes pipeline (IMG/ER [85];). Pairwise average nucleotide identity between the genomes was evaluated within both the IMG interface and with orthoANI [71].

\section{Comparative genomic analysis}

A comparative genomic analysis was performed between the piezophilic and non-piezophilic strains of Colwellia to identify whole-genome changes and specific genes unique to piezophiles. The isoelectric point (pI) of each predicted proteome was calculated using the compute $\mathrm{pI} / \mathrm{MW}$ tool in the ExPASy Bioinformatics Resource Portal [8]. Isoelectric point values from ExPASy were rounded to the nearest tenth and the frequency of each protein pI was plotted in Fig. 2a as a percent of the total proteome. Each proteome was divided into an acidic set of proteins $\left(\mathrm{pI}<7 ; \mathrm{N}_{\mathrm{a}}\right)$ and a basic set $\left(\mathrm{pI}>7 ; \mathrm{N}_{\mathrm{b}}\right)$ and the bias quantified using the formula $\left(\left(\mathrm{N}_{\mathrm{b}}-\mathrm{N}_{\mathrm{a}}\right) /\left(\mathrm{N}_{\mathrm{b}}+\mathrm{N}_{\mathrm{a}}\right) \times\right.$ 100). The pI bias percentage is calculated such that $100 \%$ means the proteins in the entire proteome are basic, $-100 \%$ means all the proteins are acidic, and $0 \%$ means equal percentage of basic and acidic proteins.

To identify specific amino acid substitutions that may correlate with piezophily, amino acid asymmetry was calculated using the procedure and software described in McDonald et al. [90]. First, proteins from the genomes were clustered using TribeMCL ([37]; scripts available at https://github.com/juanu/MicroCompGenomics) with a Blastp cutoff of 1e-5 and an inflation value of 1.4. Orthologous single-copy gene clusters present in both the piezophiles and Colwellia psychrerythraea $34 \mathrm{H}$ were aligned using MAFFT [82] and then processed with the Asymmetry programs AmbiguityRemover (using a value of 2 for the number of adjacent sites), AsymmetryCounter, and AsymmetryScaler (with three decimal places and 100 replicates [90];). Approximately 346,000 aligned amino acid sites were examined in each comparison. Comparisons were also performed between the Shewanella strains S. benthica KT99, S. violacea DSS12, and S. piezotolerans WP3 against the piezosensitive $S$. sediminis EB3.

Protein abundances from the genomes were compared to identify attributes preferentially enriched in either the piezophiles or piezosensitive strains. General COG category distributions were evaluated using IMG/ER annotations. For the identification of differentially-abundant specific proteins, genomes were annotated using Prokka [120] and compared using Roary [103] at a similarity cut off of $70 \%$ identity. Gene distributions were visualized using Phandango [48]. Protein clusters were also generated using the TribeMCL analysis as described above. Identified protein clusters using these techniques were further screened using blastp [4] against the $\mathrm{nr}$ database for their prevalence in other Colwellia genomes, other piezophile genomes, or other metagenomes. This manual curation allowed for the identification of both genes 
differentially abundant within the groups of genomes immediately discussed here but also allowed for a culled, smaller dataset of genes that may be present in other deep-ocean isolates and datasets.

Certain genomic features within the genomes were also identified. Genomic islands were identified using IslandViewer [13]. Regions that may represent genomic islands were also identified using the Mean Shift Genomic Island Predictor (MSGIP [27];). As incomplete genomes appeared to give spurious results, the total number of genomic islands are reported only for the complete genomes of Colwellia marinimaniae MT41 and C. psychrerythraea $34 \mathrm{H}$. However, genomic islands for some of the partial genomes are shown here (e.g. Figure 4) only when IslandViewer or MSGIP identified a region as a genomic island, it was in a similar region as a genomic island found in either of the $34 \mathrm{H}$ or MT41 genomes, and it appeared to be a region of variability based on IMG/ER annotations. The homology of these variable regions was analyzed using blastn and visualized with the R package genoPlotR [46] and Kablammo [143]. Putative transposases and toxin/antitoxin genes were identified based on IMG/ER annotations. Putative viral regions of each genome were also identified based predominantly on IMG/ER annotations with a functional search using the terms 'phage' and 'virus,' but also with VirFinder [118] and VirSorter [119]. Different types of flagella and pili were annotated using MacSyFinder and TXSScan ([1]; https://galaxy.pasteur.fr/\#forms::txsscan) with default parameters. Carbohydrate-active enzymes within each genome were identified using dbCAN [152].

\section{Supplementary information}

Supplementary information accompanies this paper at https://doi.org/10 1186/s12864-020-07102-y.

Additional file 1. (XLS $38 \mathrm{~kb})$

Additional file 2 .

\section{Abbreviations}

TMAO: Trimethylamine-N-oxide; SAM: S-adenosyl-I-methionine; MPa: Megapascal; ANI: Average nucleotide identity; COG: Clusters of Orthologous Groups; pl: Isoelectric point

\section{Acknowledgements}

We thank Stephen Techtmann and Terry Hazen for providing the Colwellia psychrerythraea strains GAB14E and ND2E. Thanks to Priya Narasingarao and Sheila Podell for constructive input. We appreciate the support of the crew of the RN Revelle and those associated with the MOTT expedition for their help collecting these samples. This includes but is not limited to Rosa LeonZayas, Jenan Kharbush, Rachael Hazael, and Fabrizia Foglia. We thank Paul Yancey and Alan Jamieson for kindly providing the amphipod image in Fig. 5 .

\section{Authors' contributions}

LMP, TSK, JAU, KM, MK, RAC, AAY, BAM performed experimental and bioinformatics work. LMP, TSK, DHB performed data analysis. LMP, TSK, DHB wrote the manuscript. All authors read and approved the final manuscript.

\section{Funding}

This work was supported by funding from the National Science Foundation (1536776), the National Aeronautics and Space Administration (NNX11AG10G), the Prince Albert II Foundation (Project 1265), the Sloan Foundation Deep Carbon Observatory/Deep Life Community, and UC Ship Funds program and private donor support for the Microbial Oceanography of the Tonga Trench (MOTT) expedition. TSK was supported by an undergraduate fellowship from the UCSD Foundation.

\section{Availability of data and materials}

The genome sequences of strains MT41, MTCD1, and TT2012 have been deposited at GenBank under the accessions CP013145, GCA_001432325, and GCA_001440345, respectively. The assembled and annotated genomes of strains MT41, MTCD1, and TT2012 can be located in IMG/JGI under the IMG taxon IDs 2501651205, 2585427605, and 2585428047 respectively.

Ethics approval and consent to participate

Not applicable.

\section{Consent for publication}

Not applicable.

\section{Competing interests}

The authors declare that they have no competing interests.

\section{Author details}

${ }^{1}$ Marine Biology Research Division, Scripps Institution of Oceanography, University of California San Diego, La Jolla, CA 92093-0202, USA. ${ }^{2}$ Flathead Lake Biological Station, University of Montana, Polson, MT 59860, USA. ${ }^{3}$ Millennium Initiative for Collaborative Research on Bacterial Resistance (MICROB-R), Santiago, Chile. ${ }^{4}$ Department of Material Science, National Institute of Technology, Wakayama College, 77 Noshima, Nada-cho, Gobo, Wakayama 644-0023, Japan. ${ }^{5}$ Center for Microbiome and Medicine, University of Pittsburgh, Pittsburgh, PA 15213, USA

Received: 13 March 2020 Accepted: 24 September 2020

Published online: 06 October 2020

\section{References}

1. Abby SS, Cury J, Guglielmini J, Néron B, Touchon M, Rocha EPC. Identification of protein secretion systems in bacterial genomes. Sci Rep. 2016;6:23080.

2. Abe F. Dynamic structural changes in microbial membranes in response to high hydrostatic pressure analyzed using time-resolved fluorescence anisotropy measurement. Biophys Chem. 2013;183:3-8.

3. Allen EA, Facciotti D, Bartlett DH. Monosaturated but not polyunsaturated fatty acids are required for growth of the deep-sea bacterium Photobacterium profundum SS9 at high pressure and low temperature. Appl Environ Microbiol. 1999;65:1710-20.

4. Altschul SF, Gish W, Miller W, Myers EW, Lipman DJ. Basic local alignment search tool. J Mol Biol. 1990:215:403-10.

5. Anderson RE, Brazelton WJ, Baross JA. Is the genetic landscape of the deep subsurface biosphere affected by viruses? Front Microbiol. 2011;2:219.

6. Aono E, Baba T, Ara T, Nishi T, Nakamichi T, Inamoto E, Toyonaga H, Hasegawa M, Takai Y, Okumura Y, Baba M, Tomita M, Kato C, Oshima T, Nakasone K, Mori $\mathrm{H}$. Complete genome sequence and comparative analysis of Shewanella violacea, a psychrophilic and piezophilic bacterium from deep sea floor sediments. Mol BioSyst. 2010;6:1216-26.

7. Arrieta JM, Mayol E, Hansman RL, Herndl GJ, Dittmar T, Duarte CM. Dilution limits dissolved organic carbon utilization in the deep ocean. Science. 2015; 348:331-3.

8. Artimo P, Jonnalagedda M, Arnold K, Baratin D, Csardi G, de Castro E, Duvaud S, Flegel V, Fortier A, Grosdidier EGA, Hernandez C, loannidis V, Kuznetsov D, Liechti R, Moretti S, Mostaguir K, Redaschi N, Rossier G, Xenarios I, Stockinger H. ExPASy: SIB bioinformatics resource portal. Nucl Acid Res. 2012;40:W597-603.

9. Baker LJ, Freed LL, Easson CG, Lopez JV, Fenolio D, Sutton TT, Nyholm SV Hendry TA. Diverse deep-sea anglerfishes share a genetically reduced luminous symbiont that is acquired from the environment. eLife. 2019;8: e47606. 
10. Bankevich A, Nurk S, Antipov D, Gurevich AA, Dvorkin M, Kulikov AS, Lesin VM, Nikolenko SI, Pham S, Prjibelski AD, Pyshkin AV, Sirotkin AV, Vyahhi N, Tesler T, Alekseyev MA, Pevzner PA. SPAdes: a new genome assembly algorithm and its applications to single-cell sequencing. J Comput Biol. 2012;19:455-77.

11. Bartlett D, Chi E. Genetic characterization of ompH mutants in the deep-sea bacterium Photobacterium sp. strain SS9. Arch. Microbiol. 1994;162:323-8.

12. Bartlett $D$, Wright $M$, Yayanos $A A$, Silverman $M$. Isolation of a gene regulated by hydrostatic pressure in a deep-sea bacterium. Nature. 1989;342:572-4.

13. Bertelli C, Laird MR, Williams KP, Simon Fraser University Research Computing Group, Lau BY, Hoad G, Winsor GL, Brinkman FSL. IslandViewer 4: expanded prediction of genomic islands for larger-scale datasets. Nucl Acid Res. 2017;45:W30-W35.

14. Beszteri B, Temperton B, Frickenhaus S, Giovannoni SJ. Average genome size: a potential source of bias in comparative metagenomics. ISME J. 2010; 4:1075-7.

15. Boeuf D, Edwards BR, Eppley JM, Hu SK, Poff KE, Romano AE, Caron DA, Karl DM, DeLong EF. Biological composition and microbial dynamics of sinking particulate organic matter at abyssal depths in the oligotrophic open ocean. Proc Natl Acad Sci. 2019;201903080.

16. Bowman JP. The family Colwelliaceae. Prokaryotes. 2014:179-95.

17. Cabello-Yeves PJ, Rodriguez-Valera F. Marine-freshwater prokaryotic transitions require extensive changes in the predicted proteome. Microbiome. 2019;7:117.

18. Campanaro S, Vezzi A, Vitulo N, Lauro FM, D'Angelo M, Simonato F, Cestaro A, Malacrida G, Bertoloni G, Valle G, Bartlett DH. Laterally transferred elements and high pressure adaptation in Photobacterium profundum strains. BMC Genomics. 2005;6:122.

19. Campanaro S, De Pascale F, Telatin A, Schiavon R, Bartlett DH, Valle G. The transcriptional landscape of the deep-sea bacterium Photobacterium profundum in both a toxR mutant and its parental strain. BMC Genomics. 2012;13:567

20. Chen SC, Sun GX, Rosen BP, Zhang SY, Deng Y, Zhu BK, Rensing C, Zhu YG. Recurrent horizontal transfer of arsenite methyltransferase genes facilitated adaptation of life to arsenic. Sci Rep. 2017;7:7741.

21. Chi E, Bartlett DH. An rpoE-like locus controls outer membrane protein synthesis and growth at cold temperatures and high pressures in the deepsea bacterium Photobacterium sp. strain SS9. Mol Microbiol. 1995;17:713-26.

22. Chikuma S, Kasahara R, Kato C, Tamegai H. Bacterial adaptation to high pressure: a respiratory system in the deep-sea bacterium Shewanella violacea DSS12. FEMS Microbiol Lett. 2007;267:108-12.

23. Colangelo-Lillis JR, Deming JW. Genomic analysis of cold-active Colwelliaphage $9 \mathrm{~A}$ and psychrophilic phage-host interactions. Extremophiles. 2013;17:99-114.

24. Collins RE, Deming JW. An inter-order horizontal gene transfer event enables the catabolism of compatible solutes by Colwellia psychrerythraea 34H. Extremophiles. 2013;17:601-10.

25. Dalmasso C, Oger P, Selva G, Courtine D, L'Haridon S, Garlaschelli A, Roussel E, Miyazaki J, Reveillaud J, Jebbar M, Takai K, Maignien L, Alain K. Thermococcus piezophilus sp. nov., a novel hyperthermophilic and piezophilic archaeon with a broad pressure range for growth, isolated from a deepest hydrothermal vent at the mid-Cayman rise. Syst Appl Microbiol. 2016:39:440-4

26. Paul S, Bag SK, Das S, Harvill ET, Dutta C. Molecular signature of hypersaline adaptation: insights from genome and proteome composition of halophilic prokaryotes. Genome Biol. 2008;9:R70.

27. De Brito DM, Maracaja-Coutinho V, de Farias ST, Batista LV, do Rêgo TG. A novel method to predict genomic islands based on mean shift clustering algorithm. PLoS One. 2016;11:e0146352.

28. DeLong E, Franks DG, Yayanos AA. Evolutionary relationships of cultivated psychrophilic and barophilic deep-sea bacteria. Appl Environ Microbiol. 1997:63:2105-8.

29. DeLong EF, Yayanos AA. Adaptation of the membrane lipids of a deep-sea bacterium to changes in hydrostatic pressure. Science. 1985;228:1101-3.

30. DeLong EF, Yayanos AA. Biochemical function and ecological significance of novel bacterial lipids in deep-sea procaryotes. Appl Environ Microbiol. 1986; 51:730-7.

31. DeLong EF, Preston CM, Mincer T, Rich V, Hallam SJ, Frigaard N, Martinez A, Sullivan MB, Edwards R, Rodriguez Brito B, Chisholm SW, Karl DM. Community genomics among stratified microbial assemblages in the ocean's interior. Science. 2006;311:496-503.
32. Deming JW, Somers LK, Straube WL, Swartz DG, Macdonell MT. Isolation of an obligately barophilic bacterium and description of a new genus, Colwellia gen. Nov. Systemic and Applied Microbiology. 1988;10:152-60.

33. Di Giulio M. A comparison of proteins from Pyrococcus furiosus and Pyrococcus abyssi: barophily in the physicochemical properties of amino acids and in the genetic code. Gene. 2005;346:1-6.

34. Dombrowski N, Teske AP, Baker BJ. Expansive microbial metabolic versatility and biodiversity in dynamic Guaymas Basin hydrothermal sediments. Nat Commun. 2018;9:4999.

35. Dyksma S, Bischof K, Fuchs BM, Hoffmann K, Meier D, Meyerdierks A, Pjevac P, Probandt D, Richter M, Stepanauskas R, Mußmann M. Ubiquitous Gammaproteobacteria dominate dark carbon fixation in coastal sediments. ISME J. 2016;10:1939-53.

36. El-Hajj ZW, Tryfona T, Allcock DJ, Hasan F, Lauro FM, Sawyer L, Bartlett DH, Ferguson GP. Importance of proteins controlling initiation of DNA replication in the growth of the high-pressure-loving bacterium Photobacterium profundum SS9. J Bacteriol. 2009;191:6383-93.

37. Enright AJ, Van Dongen S, Ouzounis CA. An efficient algorithm for largescale detection of protein families. Nucl Acid Res. 2002;30:1575-84.

38. Eloe EA, Lauro FM, Vogel RF, Bartlett DH. The deep-sea bacterium Photobacterium profundum SS9 utilizes separate flagellar systems for swimming and swarming under high-pressure conditions. Appl Environ Microbiol. 2008;74:6298-305.

39. Eloe EA, Fadrosh DW, Novotny M, Allen LZ, Kim M, Lombardo MJ, YeeGreenbaum J, Yooseph S, Allen EE, Lasken R, Williamson SJ, Bartlett DH. Going deeper: metagenome of a hadopelagic microbial community. PLoS One. 2011;6:e20388.

40. Faruque SM, Mekalanos JJ. Pathogenicity islands and phages in Vibrio cholerae evolution. Trends Microbiol. 2013;11:505-10.

41. Feng Z, Caceres NE, Sarath G, Barletta RG. Mycobacterium smegmatis Lalanine dehydrogenase (Ald) is required for proficient utilization of alanine as a sole nitrogen source and sustained anaerobic growth. J Bacteriol. 2002; 184:5001-10.

42. Feng $\mathrm{S}$, Powell SM, Wilson R, Bowman JP. Extensive gene acquisition in the extremely psychrophilic bacterial species Psychroflexus torquis and the link to sea-ice ecosystem specialism. Genome Biol Evol. 2014;6:133-48.

43. Fontanez KM, Eppley JM, Samo TJ, Karl DM, DeLong EF. Microbial community structure and function on sinking particles in the North Pacific subtropical gyre. Front Microbiol. 2015;6:469.

44. Gallegos MT, Schleif R, Bairoch A, Hofmann K, Ramos JL. Arac/XylS family of transcriptional regulators. Microbiol Mol Biol Rev. 1997;61:393-410.

45. Ganesh S, Parris DJ, DeLong EF, Stewart FJ. Metagenomic analysis of sizefractionated picoplankton in a marine oxygen minimum zone. ISME J. 2014; 8:187-211.

46. Guy L, Kultima JR, Andersson SGE. genoPlotR: comparative gene and genome visualization in R. Bioinformatics. 2010;26:2334-5.

47. Guelorget A, Roovers M, Guérineau V, Barbey C, Li X, Golinelli-Pimpaneau B. Insights into the hyperthermostability and unusual region-specificity of archaeal Pyrococcus abyssi tRNA m ${ }^{1}$ A57/58 methyltransferase. Nucl Acid Res. 2010;38:6206-18.

48. Hadfield J, Croucher NJ, Goater RJ, Abudahab K, Aanensen DM, Harris SR. Phandango: an interactive viewer for bacterial population genomics. Bioinformatics. 2018;34:292-3.

49. Hoffmann K, Hassenrück C, Salman-Carvalho V, Holtappels M, Bienhold C. Response of bacterial communities to different detritus compositions in Arctic deep-sea sediments. Front Microbiol. 2017;8:226.

50. Holtwick R, Meinhardt F, Keweloh H. cis-trans isomerization of unsaturated fatty acids: Cloning and sequencing of the cti gene from Pseudomonas putida P8. Appl Environ Microbiol. 1997;63:4292-7.

51. Hu P, Dubinsky EA, Probst AJ, Wang J, Sieber CMK, Tom LM, et al. Simulation of oil plume reveals substrate specialization within a complex community of hydrocarbon degraders. Proc Natl Acad Sci. 2017;114(28): 7432-7437.

52. Hummer $G$, Garde S, Garcia AE, Paulaitis ME, Pratt LR. The pressure dependence of hydrophobic interactions is consistent with the observed pressure denaturation of proteins. Proc Natl Acad Sci. 1998;95:1552-5.

53. Huston AL, Krieger-Brockett BB, Deming JW. Remarkably low temperature optima for extracellular enzyme activity from Arctic bacteria and sea ice. Environ Microbiol. 2000;2:383-8.

54. Hutter B, Dick T. Incrased alanine dehydrogenase activity during dormancy in Mycobacterium spegmatis. FEMS Microbiol Lett. 1998;167:7-11. 
55. Ivars-Martinez E, Martin-Cuadrado AB, D'Auria G, Mira A, Ferriera S, Johnson J, Friedman R, Rodriguez-Valera F. Comparative genomics of two ecotypes of the marine planktonic copiotroph Alteromonas macleodii suggests alternative lifestyles associated with different kinds of particulate organic matter. ISME J. 2008;2:1194-212.

56. Jebbar M, Franzetti B, Girard E, Oger P. Microbial diversity and adaptation to high hydrostatic pressure in deep-sea hydrothermal vents prokaryotes. Extremophiles. 2015;19:721-40.

57. Jeong JA, Oh Jl. Alanine dehydrogenases in mycobacteria. J Microbiol. 2019; 57:81-92.

58. Jun X, Lupeng L, Minjuan X, Oger P, Fengping W, Jebbar M, Xiang X. Complete genome sequence of the obligate piezophilic hyperthermophilic archaeon Pyrococcus yayanosii CH1. J Bacteriol. 2011;193:4297-8.

59. Kiraga J, Mackiewicz P, Mackiewicz D, Kowalczuk M, Biecek P, Polak N, Smolarczyk K, Dudek MR, Cebrat S. The relationships between the isoelectric point and: length of proteins, taxonomy and ecology of organisms. BMC Genomics. 2007;8:163.

60. Kleindienst S, Seidel M, Ziervogel K, Grim S, Loftis K, Harrison S, Malkin SY, Perkins MJ, Field J, Sogin ML, Dittmar T, Passow U, Medeiros PM, Joye SB. Chemical dispersants can suppress the activity of natural oil-degrading microoganisms. Proc Natl Acad Sci. 2015;112:14900-5.

61. Konstantinidis KT, Braff J, Karl DM, DeLong EF. Comparative metagenomic analysis of a microbial community residing at a depth of 4,000 meters at station ALOHA in the North Pacific subtropical gyre. Appl Environ Microbiol. 2009;75:5345-55

62. Kusube M, Kyaw TS, Tanikawa K, Chastain RA, Hardy KM, Cameron J, Bartlett $\mathrm{DH}$. Colwellia marinimaniae sp. nov., a hyperpiezophilic species isolated from an amphipod within the challenger deep, Mariana trench. Int I Sys Evol Microbiol. 2017;67:824-31.

63. Kyrpides NC, Woyke T, Eisen JA, Garrity G, Lilburn TG, Beck BJ, Whitman WB, Hugenholtz P, Klenk HP. Genomic encyclopedia of type strains, phase I: the one thousand microbial genomes (KMG-I) project. Stand Genomic Sci. 2014; 9:9031278.

64. Landry Z, Swan BK, Herndl GJ, Stepanauskas R, Giovannoni SJ. SAR202 genomes from the dark ocean predict pathways for the oxidation of recalcitrant dissolved organic matter. mBio. 2017:8:e00413-7.

65. Lauro FM, Chastain RA, Blankenship LE, Yayanos AA, Bartlett DH. The unique $16 \mathrm{~S}$ rRNA genes of piezophiles reflect both phylogeny and adaptation. Appl Environ Microbiol. 2007a;73:838-45.

66. Lauro FM, Tran K, Vezzi A, Vitulo N, Valle G, Bartlett DH. Large-scale transposon mutagenesis of Photobacterium profundum SS9 reveals new genetic loci important for growth at low temperature and high pressure. J Bacteriol. 2007b;190:1699-709.

67. Lauro FM, Bartlett DH. Prokaryotic lifestyles in deep sea habitats. Extremophiles. 2008;12:15-25.

68. Lauro FM, Chastain RA, Ferriera S, Johnson J, Yayanos AA, Bartlett DH. Draft genome sequence of the deep-sea bacterium Shewanella benthica strain KT99. Genome Announc. 2013a;1:e00210-3.

69. Lauro FM, Stratton TK, Chastain RA, Ferriera S, Johnson J, Goldberg SMD, Yayanos AA, Bartlett DH. Complete genome sequence of the deep-sea bacterium Psychromonas strain CNPT3. Genome Announc. 2013b;1:e00304-13.

70. Lauro FM, Eloe-Fadrosh EA, Richter TKS, Vitulo N, Ferriera S, Johnson JH, Bartlett DH. Ecotype diversity and conversion in Photobacterium profundum strains. PLoS One. 2014;9:e96953.

71. Lee I, Kim YO, Park SC, Chun J. OrthoANI: an improved algorithm and software for calculating average nucleotide identity. Int J Sys Evol Microbiol. 2016;66:1100-3.

72. Leon-Zayas R, Novotny M, Podell S, Shepard CM, Berkenpas E, Nikolenko S, Pevzner P, Lasken RS, Bartlett DH. Single cells within the Puerto Rico trench suggest hadal adaptation of microbial lineages. Appl Environ Microbiol. 2015;81:8265-76

73. Letunic I, Bork P. Interactive tree of life (iTOL) v3: an online tool for the display and annotation of phylogenetic and other trees. Nucl Acid Res. 2016;44:W242-5.

74. Li Z, Li X, Xiao X, Xu J. An integrative genomic island affects the adaptations of the piezophilic hyperthermophilic archaeon Pyrococcus yayanosii to high temperature and high hydrostatic pressure. Front Microbiol. 2016;7:1927.

75. Li Z, Song Q, Wang Y, Xiao X, Xu J. Identification of a functional toxin-antitoxin system located in the genomic island PYG1 of piezophilic hyperthermophilic archaeon Pyrococcus yayanosii. Extremophiles. 2018:22:347-57.
76. Loffeld B, Keweloh $\mathrm{H}$. cis/trans isomerization of unsaturated fatty acids as possible control mechanism of membrane fluidity in Pseudomonas putida P8. Lipids. 1996;31:811-5.

77. Lossouarn J, Dupont S, Gorlas A, Mercier C, Bienvenu N, Marguet E, Forterre P, Geslin C. An abyssal mobilome: viruses, plasmids, and vesicles from deepsea hydrothermal vents. Res Microbiol. 2015;166:742-52.

78. Lucas S, Han J, Lapidus A, Cheng JF, Goodwin LA, Pitluck S, Peters L, Mikhailova N, Teshima H, Detter JC, Han C, Tapia R, Land M, Hauser L, Kyrpides NC, Ivanova N, Pagani I, Vannier P, Oger P, Bartlett DH, Noll KM, Woyke T, Jebbar M. Complete genome sequence of the thermophilic, piezophilic, heterotrophic bacterium Marinitoga piezophila KA3. J Bacteriol. 2012;194:5974-5.

79. Luo H, Tolar BB, Swan BK, Zhang CL, Stepanauskas R, Moran MA, Hollibaugh JT. Single-cell genomics shedding light on marine Thaumarchaeota diversification. ISME J. 2014:8:732-6.

80. Maddocks SE, Oyston PCF. Structure and function of the LysR-type transcriptional regulator (LTTR) family proteins. Microbiology. 2008;154: 3609-23.

81. Martin D, Bartlett DH, Roberts MF. Solute accumulation in the deep-sea bacterium Photobacterium profundum. Extremophiles. 2002;6:507-14.

82. Katoh $\mathrm{K}$, Toh $\mathrm{H}$. Recent developments in the MAFFT multiple sequence alignment program. Brief Bioinform. 2008;9:286-98.

83. Magoč T, Salzberg SL. FLASH: fast length adjustment of short reads to improve genome assemblies. Bioinformatics. 2011;27:2957-63.

84. Mao D, Grogan DW. How a genetically stable extremophile evolves: modes of genome diversification in the Archaeon Sulfolobus acidocaldarius. J Bacteriol. 2017;199:e00177-17.

85. Markowitz VM, Chen IMA, Palaniappan K, Chu K, Szeto E, Pillay M, Ratner A, Huang J, Woyke T, Anderson MHI, Billis K, Varghese N, Mavromatis K, Pati A, Ivanova NN, Kyrpides NC. IMG 4 version of the integrated microbial genomes comparative analysis system. Nucl Acid Res. 2014;42:D560-7.

86. Martin-Cuadrado AB, Lopez-Garcia P, Alba JC, Moreira D, Monticelli L, Strittmatter A, Gottschalk G, Rodriguez-Valera F. Metagenomics of the deep Mediterranean, a warm bathypelagic habitat. PLoS One. 2007;9:e914.

87. Marx JG, Carpenter SD, Deming JW. Production of cryoprotectant extracellular polysaccharide substances (EPS) by the marine psychrophilic bacterium Colwellia psychrerythraea strain $34 \mathrm{H}$ under extreme conditions. Can J Microbiol. 2009;55:63-72.

88. Mason OU, Han J, Woyke T, Jansson JK. Single-cell genomics reveals features of a Colwellia species that was dominant during the Deepwater horizon oil spill. Front Microbiol. 2014;5:332.

89. McCutcheon JP, Moran NA. Extreme genome reduction in symbiotic bacteria. Nat Rev Microbiol. 2012;10:13-26.

90. McDonald JH, Grasso AM, Rejto LK. Patterns of temperature adaptation in proteins from Methanococcus and bacillus. Mol Biol Evol. 1999;16:1785-90.

91. Methé BA, Nelson KE, Deming JW, Momen B, Melamud E, Zhang X, Moult J, Madupu R, Nelson WC, Dodson RJ, Brinkac LM, Daugherty SC, Durkin AS, DeBoy RT, Kolonay JF, Sullivan SA, Zhou L, Davidsen TM, Wu M, Huston AL, Lewis M, Weaver B, Weidman JF, Khouri H, Utterback TR, Feldblyum TV, Fraser CM. The psychrophilic lifestyle as revealed by the genome sequence of Colwellia psychrerythraea $34 \mathrm{H}$ through genomic and proteomic analyses. Proc Natl Acad Sci. 2005;102:10913-8.

92. Michoud G, Jebbar M. High hydrostatic pressure adaptive strategies in an obligate piezophile Pyrococcus yayanosii. Sci Rep. 2016;6:27289.

93. Miller MA, Pfeiffer W, Schwartz T. Creating the CIPRES Science Gateway for inference of large phylogenetic trees. In 2010 Gateway Computing Environments Workshop (GCE). 2010;1-8.

94. Mußmann M, Pjevac P, Krüger K, Dyksma S. Genomic repertoire of the Woeseiaceae/JTB255, cosmopolitan and abundant core members of microbial communities in marine sediments. ISME J. 2017;11:1276-81.

95. Nakayama A, Saito R, Matsuzaki M, Yano Y, Yoshida K. Phylogenetic analysis based on 165 rRNA gene sequences of deep-sea bacteria isolated from intestinal contents of deep-sea fishes retrieved from the abyssal zone. J Gen Appl Microbiol. 2005;51:385-94.

96. Navarro CA, von Bernath D, Jerez CA. Heavy metal resistance strategies of acidophilic bacteria and their acquisition: importance for biomining and bioremediation. Biol Res. 2013;46:363-71.

97. Nogi Y, Hosoya S, Kato C, Horikoshi K. Colwellia piezophila sp. nov., a novel piezophilic species from deep-sea sediments of the Japan trench. Int J Sys Evol Microbiol. 2004:54:1627-31. 
98. Nogi Y. Microbial life in the deep sea: Psychropiezophiles. In: Margesin R, editor. Psychrophiles: from biodiversity to biotechnology. Cham: Springer; 2017. p. 133-52.

99. Nunn BL, Slattery KV, Cameron KA, Timmins-Schiffman E, Junge K. Proteomics of Colwellia psychrerythraea at subzero temperatures - a life with limited movement, flexible membranes and vital DNA repair. Environ Microbiol. 2015;17:2319-35.

100. Oger PM, Jebbar M. The many ways of coping with pressure. Res Microbiol. 2010;161:799-809.

101. Orellana $\mathrm{LH}$, Jerez CA. A genomic island provides Acidithiobacillus ferrooxidans ATCC 53993 additional copper resistance: a possible competitive advantage. Appl Microbiol Biotech. 2011;92:761.

102. Pachiadaki MG, Sintes E, Bergauer K, Brown JM, Record NR, Swan BK, Mathyer ME, Hallam SJ, Lopez-Garcia P, Takaki Y, Nunoura T, Woyke T, Herndl GJ, Stepanauskas R. Major role of nitrite-oxidizing bacteria in dark ocean carbon fixation. Science. 2017;358:1046-51.

103. Page AJ, Cummins CA, Hunt M, Wong VK, Reuter S, Holden MTG, Fookes M, Falush D, Keane JA, Parkhill J. Roary: rapid large-scale prokaryote pan genome analysis. Bioinformatics. 2015;31:3691-3.

104. Pante E, Simon-Bouhet B. marmap: A package for importing, plotting, and analyizng bathymetric and topographic data in R. PLoS One. 2013; 8:e73051.

105. Parks DH, Imelfort M, Skennerton CT, Hugenholtz P, Tyson GW. CheckM: assessing the quality of microbial genomes recovered from isolates, single cells, and metagenomes. Genome Res. 2015;25:1043-55.

106. Peoples LM, Bartlett DH. Ecogenomics of deep-ocean microbial bathytypes. In: Chénard C, Lauro FM, editors. Microbial ecology of extreme environments. Springer: Cham; 2017. p. 7-50.

107. Peoples LM, Donaldson S, Osuntokun O, Xia Q, Nelson A, Blanton J, Allen EE, Church MJ, Bartlett DH. Vertically distinct microbial communities in the Mariana and Kermadec trenches. PLoS One. 2018;13:e0195102.

108. Peoples LM. Composition and Functional Potential of Hadal Microbial Communities. eScholarship, University of California; 2018.

109. Peoples LM, Grammatopoulou E, Pombrol M, Xu X, Osuntokun O, Blanton J, Allen EE, Nunnally CC, Drazen JC, Mayor DJ, Bartlett DH. Microbial community diversity within sediments from two geographically separated hadal trenches. Front Microbiol. 2019a;10:347.

110. Peoples LM, Norenberg M, Price D, McGoldrick M, Novotny M, Bochdansky A, Bartlett DH. A full-ocean depth rated modular lander and pressureretaining sampler capable of collecting hadal-endemic microbes under in situ conditions. Deep Sea Res Pt 1. 2019b;143:50-57.

111. Pinchuk EG, Hill EA, Geydebrekht OV, De Ingeniis J, Zhang X, Osterman A, Scott JH, Reed SB, Romine MF, Konopka AE, Beliaev AS, Fredrickson JK, Reed J. Constraint-based model of Shewanella oneidensis MR-1 metabolism: a tool for data analysis and hypothesis generation. PLoS One. 2010;6: e1000822.

112. Planet PJ, Kachlany SC, Fine DH, DeSalle R, Figurski DH. The widespread colonization island of Actinobacillus actinomycetemcomitans. Nat Genet. 2003;34:193-8

113. Pradel N, Ji B, Gimenez G, Talla E, Lenoble P, Garel M, Tamburini C, Fourquet P, Lebrun R, Bertin P, Denis Y, Pophillat M, Barbe V, Ollivier B, Dolla A. The first genomic and proteomic characterization of a deep-sea sulfate reducer: insights into the piezophilic lifestyle of Desulfovibrio piezophilus. PLoS One. 2013;8:e55130.

114. Pruesse E, Peplies J, Glöckner FO. SINA: accurate high-throughput multiple sequence alignment of ribosomal RNA genes. Bioinformatics. 2012;28:1823-9.

115. Pu M, Duriez P, Arazi M, Rowe-Magnus DA. A conserved tad pilus promotes Vibrio vulnificus oyster colonization. Environ Microbiol. 2018;20:828-41.

116. Qin QL, Li Y, Zhang YJ, Zhou ZM, Zhang WX, Chen XL, Zhang XY, Zhou BC, Wang L, Zhang YZ. Comparative genomics reveals a deep-sea sedimentadapted life style of Pseudoalteromonas sp. SM9913. ISME J. 2011:5:274

117. Redmond MC, Valentine DL. Natural gas and temperature structured a microbial community response to the Deepwater horizon oil spill. Proc Nat Acad Sci. 2012;109:20292-7.

118. Ren J, Ahlgren NA, Lu YY, Fuhrman JA, Sun F. VirFinder: a novel k-mer based tool for identifying viral sequences from assembled metagenomic data. Microbiome. 2017:5:69.

119. Roux S, Enault F, Hurwitz BL, Sullivan MB. VirSorter: mining viral signal from microbial genomic data. PeerJ. 2015;3:e985.

120. Seemann T. Prokka: rapid prokaryotic genome annotation. Bioinformatics. 2014;30:2068-9
121. Showalter GM, Deming JW. Low-temperature chemotaxis, halotaxis and chemohalotaxis by the psychrophilic marine bacterium Colwellia psychrerythraea 34H. Environ Microbiol Rep. 2018;10:92-101.

122. Simonato F, Campanaro S, Lauro FM, Vezzi A, D'Angelo M, Vitulo N, Valle G, Bartlett DH. Piezophilic adaptation: a genomic point of view. J Biotechnol. 2006;126:11-25

123. Simpson RK, Gilmour A. The effect of high hydrostatic pressure on the activity of intraceullar enzyems of Listeria monocytogenes. Lett Appl Microbiol. 1997;25:48-53.

124. Smedile F, Messina E, La Cono V, Tsoy O, Monticelli LS, Borghini M, Giuliano L, Golyshin PN, Mushegian A, Yakimov MM. Metagenomic analysis of hadopelagic microbial assemblages thriving at the deepest part of the Mediterranean Sea, Matapan-Vavilov Deep. Environ Microbiol. 2013;15:167-82.

125. Somero GN. Protein adaptations to temperature and pressure: complementary roles of adaptive changes in amino acid sequence and internal milieu. Comp Biochem Physiol B: Biochem Mol Biol. 2003;136:577-91.

126. Stamatakis A. RAxML version 8: a tool for phylogenetic analysis and postanalysis of large phylogenies. Bioinformatics. 2014;30:1312-3.

127. Sutton GG, White O, Adams MD, Kerlavage AR. TIGR assembler: a new tool for assembling large shotgun sequencing projects. Genome Sci Technol. 1995;1:9-19.

128. Somero GN. Adaptations to high hydrostatic pressure. Annu Rev Physiol. 1992;1:557-77.

129. Swan BK, Martinez-Garcia M, Preston CM, Sczyrba A, Woyke T, Lamy D, Reinthaler T, Poulton NJ, Masland EDP, Gomez ML, Sieracki ME, DeLong EF, Herndl GJ, Stepanauskas R. Potential for chemolithoautotrophy among ubiquitous bacteria lineages in the dark ocean. Science. 2011;333:1296-300.

130. Swan BK, Chaffin MD, Martinez-Garcia M, Morrison HG, Field EK, Poulton NJ, Masland EDP, Harris CC, Sczyrba A, Chain PSG, Koren S, Woyke T, Stepanauskas R. Genomic and metabolic diversity of marine group I Thaumarchaeota in the mesopelagic of two subtropical gyres. PLoS One. 2014;9:e95380

131. Tabor PS, Deming JW, Ohwada K, Colwell RR. Activity and growth of microbial populations in pressurized deep-sea sediment and animal gut samples. Appl Environ Microbiol. 1982;44:413-22.

132. Tamegai H, Nishikawa S, Haga M, Bartlett DH. The respiratory system of the piezophile Photobacterium profundum SS9 grown under various pressures. Biosci Biotechnol Biochem. 2012;76:1506-10.

133. Tarn J, Peoples LM, Hardy K, Cameron J, Bartlett DH. Identification of freeliving and particle-associated microbial communities present in hadal regions of the Mariana trench. Front Microbiol. 2016;7:665.

134. Techtmann SM, Fitzgerald KS, Stelling SC, Joyner DC, Uttukar SM, Harris AP, Alshibli NK, Brown SD. Hazen TC. Front Environ Sci. 2016;4:33.

135. Thrash JC, Temperton B, Swan BK, Landry ZC, Woyke T, DeLong EF, Stepanauskas R, Giovannoni SJ. Single-cell enabled comparative genomics of a deep ocean SAR11 bathytype. ISME J. 2014;8:1440-51.

136. Tomich M, Planet PJ, Figurski DH. The tad locus: postcards from the widespread colonization island. Nat Rev Microbiol. 2007:5:363-75.

137. Tully BJ, Wheat CG, Glazer BT, Huber JA. A dynamic microbial community with high functional redundancy inhabits the cold, oxic subseafloor aquifer. ISME J. 2018;12:1-16.

138. Usui K, Hiraki T, Kawamoto J, Kurihara T, Nogi Y, Kato C, Abe F. Eicosapentaenoic acid plays a role in stabilizing dynamic membrane structure in the deep-sea piezophile Shewanella violacea: a study employing high-pressure time-resolved fluorescence anisotropy measurement. Biochim Biophys Acta. 2012;1818:574-83.

139. Vannier $P$, Marteinsson VT, Fridjonsson $O H$, Oger $P$, Jebbar M. Complete genome sequence of the hyperthermophilic, pezophilic, heterotrophic, and carboxydotrophic archaeon Thermococcus barophilus MP. J Bacteriol. 2011;193:1481-2.

140. Vannier P, Michoud G, Oger P, Marteinsson V, Jebbar M. Genome expression of Thermococcus barophilus and Thermococcus kodakarensis in response to different hydrostatic pressure conditions. Res Microbiol. 2015;166:717-25.

141. Vezzi A, Campanaro S, D'angelo M, Simonato F, Vitulo N, Lauro FM, Cestaro A, Malacrida G, Simionati B, Cannata N, Romualdi C, Bartlett DH, Valle G. Life at depth: Photobacterium profundum genome sequence and expression analysis. Science. 2005;307:1459-61

142. Wang F, Wang J, Jian H, Zhang B, Li S, Wang F, Zeng X, Gao L, Bartlett DH, Yu J, Hu S, Xiao X. Environmental adaptation: genomic analysis of the piezotolerant and psychrotolerant deep-sea iron reducing bacterium Shewanella piezotolerans WP3. PLoS One. 2008;3:e1937.

143. Wintersinger JA, Wasmuth JD. Kablammo: an interactive, web-based BLAST results visualizer. Bioinformatics. 2015;31:1305-6. 
144. Xiong $L$, Jian $H$, Zhang $Y$, Xiao $X$. The two sets of DMSO respiratory systems of Shewanella piezotolerans WP3 are involved in deep sea environmental adaptation. Front Microbiol. 2016;7:1418.

145. Yamada M, Nakasone K, Tamegai H, Kato C, Usami R, Horikoshi K. Pressure regulation of soluble cytochromes $\mathrm{C}$ in a deep-sea piezophilic bacterium, Shewanella violacea. J Bacteriol. 2000;182:2945.

146. Yancey PH. Organic osmolytes as compatible, metabolic and counteracting cryoprotectants in high osmolarity and other stresses. J Experiment Biol. 2005;208:2819-30.

147. Yancey PH, Fyfe-Johnson AL, Kelly RH, Walker VP, Auñón MT. Trimethylamine oxide counteracts effects of hydrostatic pressure on proteins of deep-sea teleosts. J Experimental Zoology. 2001;289:172-6.

148. Yancey PH, Gerringer ME, Drazen JC, Rowden AA, Jamieson A. Marine fish may be biochemically constrained from inhabiting the deepest ocean depths. Proc Natl Acad Sci. 2014;111:4461-5.

149. Yano $Y$, Nakayama A, Ishihara K, Saito H. Adaptive changes in membrane lipids of barophilic bacteria in response to changes in growth pressure. Appl Environ Microbiol. 1998;64:479-85.

150. Yayanos AA. Evolutional and ecological implications of the properties of deep-sea barophilic bacteria. Proc Natl Acad Sci. 1986;83:9542-6.

151. Yayanos AA, Dietz AS, Van Boxtel R. Obligately barophilic bacterium from the Mariana trench. Proc Natl Acad Sci. 1981;78:5212-5.

152. Yin Y, Mao X, Yang J, Chen X, Mao F, Xu Y. dbCAN: a web resource for automated carbohydrate-active enzyme annotation. Nucl Acids Res. 2012;40: W445-51.

153. Zhang W, Tian RM, Sun J, Bougouffa S, Ding W, Cai L, Lan Y, Tong H, Li Y, Jamieson AJ, Bajic VB, Drazen JC, Bartlett D, Qian PY. Genome reduction in Psychromonas species within the gut of an amphipod from the ocean's deepest point. mSystems. 2018;3:e00009-18.

154. Zhang W, Watanabe HK, Ding W, Lan Y, Tian RM, Sun J, Chen C, Cai L, Li Y, Oguri K, Toyofuku T, Kitazato H, Drazen JC, Bartlett D, Qian PY. Gut microbial divergence between two populations of the hadal amphipod Hirondellea gigas. Appl Environ Microbiol. 2019a;85:e02032-18.

155. Zhang WJ, Cui XH, Chen LH, Yang J, Li XG, Zhang C, Barbe V, Mangenot S, Fouteau S, Guerin T, Kato C, Wu LF. Complete genome sequence of Shewanella benthica DB21MT-2, an obligate piezophilic bacterium isolated from the deepest Mariana trench sediment. Mar Gen. 2019b;44:52-6.

\section{Publisher's Note}

Springer Nature remains neutral with regard to jurisdictional claims in published maps and institutional affiliations.

Ready to submit your research? Choose BMC and benefit from:

- fast, convenient online submission

- thorough peer review by experienced researchers in your field

- rapid publication on acceptance

- support for research data, including large and complex data types

- gold Open Access which fosters wider collaboration and increased citations

- maximum visibility for your research: over $100 \mathrm{M}$ website views per year

At $\mathrm{BMC}$, research is always in progress.

Learn more biomedcentral.com/submissions 